\title{
Mid-Career Teachers: A Mixed Methods Scoping Study of Professional Development, Career Progression and Retention
}

\author{
Josephine Booth $^{1, *}$, Mike Coldwell ${ }^{1}{ }^{\mathbb{C}}$, Lisa-Maria Müller ${ }^{2}$, Emily Perry ${ }^{1, * \mathbb{C}}$ and James Zuccollo ${ }^{3}$ \\ 1 Sheffield Institute of Education, Sheffield Hallam University, Sheffield S1 1WB, UK; m.r.coldwell@shu.ac.uk \\ 2 Chartered College of Teaching, Pears Pavilion, Coram Campus, 41 Brunswick Square, \\ London WC1N 1AZ, UK; lmuller@chartered.college \\ 3 Education Policy Institute, London SW1W 9TR, UK; james.zuccollo@epi.org.uk \\ * Correspondence: josephine.booth@shu.ac.uk (J.B.); e.perry@shu.ac.uk (E.P.)
}

check for

updates

Citation: Booth, J.; Coldwell, M.; Müller, L.-M.; Perry, E.; Zuccollo, J. Mid-Career Teachers: A Mixed

Methods Scoping Study of

Professional Development, Career Progression and Retention. Educ. Sci. 2021, 11, 299. https://doi.org/ 10.3390/educsci11060299

Academic Editors: Beng Huat See and Rebecca Morris

Received: 30 April 2021

Accepted: 11 June 2021

Published: 16 June 2021

Publisher's Note: MDPI stays neutral with regard to jurisdictional claims in published maps and institutional affiliations.

Copyright: (c) 2021 by the authors. Licensee MDPI, Basel, Switzerland. This article is an open access article distributed under the terms and conditions of the Creative Commons Attribution (CC BY) license (https:/ / creativecommons.org/licenses/by/ $4.0 /)$.

\begin{abstract}
Globally, there are ongoing problems with teacher retention, leading to a loss of experience and expertise. In policy and research, the emphasis is often on the professional development and retention of early career teachers, whereas teachers in later stages of their career are relatively underrepresented. This article addresses this imbalance, reporting on a mixed methods scoping study that explores definitions of mid-career teachers in England and their retention and development, via a literature review, primary data collection and secondary analysis of data from the OECD's TALIS 2018 survey. We found that there is no agreed definition of mid-career teacher, relating to time in teaching, role and wider life circumstances and self-definition. Whatever definition is used, mid-career teachers are a heterogenous group, with varying needs, career plans and commitment to the profession. Whilst typically confident in their practice, their learning needs vary and are often experienced as unmet, especially for those looking for progression routes outside leadership and those with family commitments. This indicates that their potential for career development to benefit the profession may not be reached. The article concludes with suggestions for further study, policy and practice to improve understanding of this under-researched group.
\end{abstract}

Keywords: mid-career teacher; teacher development; teacher retention; teacher careers; scoping study

\section{Introduction}

There is global concern with teacher retention [1,2]. Many countries, including the United States [3-5], Australia [6,7] and some European nations [8], report longstanding and increasing problems with teachers leaving the profession. The situation is complex: teacher retention appears to be variable across contexts, with more acute problems in some subject areas, in more remote geographical and socio-economically deprived locations and for teachers from minoritised groups [9], with further differences deriving from the support offered to teachers, especially in the early stages of their careers [10]. Research has tended to focus on the reasons for teachers leaving the profession, which include high workloads, lack of autonomy and low job satisfaction [11-13]. However, the drivers for teachers to stay in the profession and what can be done to support them, especially beyond the early years of their career, are less well-established. Therefore, there is a need for greater understanding of how policies, initiatives and support mechanisms might lead to more teachers staying in the profession, particularly beyond the first five years of their careers [6,14-16].

In England, recent figures suggest teacher recruitment and retention are critical issues [17], with missed recruitment targets across school phases, and in several subject areas, most notably physics, modern foreign languages and mathematics [18], although there are signs that the COVID-19 pandemic has driven increased recruitment to initial teacher education, which should percolate through to teacher recruitment in 2022 and beyond [19]. 
The five-year retention rate for teachers continues to drop; for those who qualified in 2014 this is just 67\% [18]. In 2019, the Department for Education (DfE) [20] reported that "even small increases in the rate of teachers leaving the profession creates significant, additional pressures on recruitment." Areas of high social and financial deprivation tend to have higher rates of teacher turnover [21,22]. More experienced teachers tend to manage their roles and promote student learning more effectively than those in the early stages of their careers [23] and so teacher attrition removes expertise from the system [22,24], with a negative impact on pupil attainment $[23,25,26]$.

Much research and policy in the area of teacher retention and attrition focuses on teachers in the early years of their careers [27,28]. Initiatives designed to support early career teachers often include professional development aiming to improve teachers' professional knowledge, efficacy, confidence and resilience (for example, [29-31]). For instance, at the time of writing, in England, the DfE's new Early Career Framework [32] is about to be rolled out nationally. This has at its heart a professional development programme, focussed on improving the retention of teachers in their first years in the profession. In relation to teachers at later stages of their careers, in England, the DfE has recently developed a suite of specialist national professional qualifications (NPQs) as professional and career development opportunities for teachers and school leaders who want to "develop their knowledge and skills in school leadership and specialist areas of teaching practice" [33]. However, it remains largely the case that the retention of teachers at later stages of their career is under-researched, and we lack an understanding of appropriate models of support, progression and development for these teachers [34,35].

In this article, we report on a mixed methods scoping study that aimed to explore what is known about mid-career teachers' retention and development. The study used three complementary approaches to address a set of related scoping questions (described below): a literature review, secondary analysis of data from the OECD's 2018 Teaching and Learning International Survey (TALIS) and primary data collection with teachers. As a result of the COVID-19 pandemic, particular attention has been paid recently to teachers' development, retention and recruitment worldwide (for example, [36]). This study largely took place before restrictions and changes to working practices were implemented in England as a response to the pandemic, and it does not attempt or intend to explore the impact of the pandemic on teachers' retention or development.

In the next section, we describe our methods. We move on to addressing the scoping questions in three findings sections, focussing on definitions of mid-career teachers, professional development, and retention and career progression. We then discuss these findings, considering where they complement and contrast each other, our confidence in what we have learned and the gaps and limitations in our findings. In conclusion, we outline opportunities for further research.

\section{Methods}

\subsection{Approach}

The questions we aimed to address through this study were:

- in what ways can we define and characterise mid-career teachers?

- how might we categorise mid-career teachers' professional development needs and how do they relate to the professional development that is typically available to teachers?

- can we identify common factors relating to the retention and career development of mid-career teachers, and, if so, what are they?

We used an initial working definition of mid-career teachers as those with five to fifteen years' experience, testing this through the study, as described below. We drew on the OECD's TALIS survey (see below) to define professional development as "activities that aim to develop an individual's skills, knowledge, expertise and other characteristics as a teacher" [37] (p. 49), and considered retention through a variety of measures, again 
described below, including teachers' likelihood to stay in or leave the profession, using job satisfaction as a proxy for this where appropriate.

Typically, scoping studies rapidly investigate the current state of the field in terms of published research through a literature review [38]. Their purpose is to map key concepts and the sources and types of evidence available and to identify gaps in the knowledge base [39-42]. In this study, a scoping literature review was supplemented with secondary analysis of publicly available data and primary data collection using quantitative and qualitative methods, as described below. Mixed methods scoping studies appear to be uncommon in education. Our extension of a literature-based scoping approach aligns with other scoping approaches, such as those found in medical literature (see, for example, $[43,44])$, in which mapping of literature, policy and concepts is supplemented by stakeholder consultation [45].

Our intention in choosing this method was to acknowledge the complex, interacting influences on teacher retention [2] by drawing on multiple sources to compare the existing literature base with current and recent national and international data to quickly test initial hypotheses about gaps in the literature (via secondary and primary data) and to gain stakeholders' responses to emerging issues (via primary data). Through this, we aimed to identify what further research could benefit school leaders, policy makers and mid-career teachers themselves to support their career development and retention in the profession.

In outline, the methods we used (Table 1) were:

- a rapid review of the literature on mid-career teachers;

- secondary analysis of data from the OECD's Teaching and Learning International Survey 2018 (TALIS) study [23];

- primary data collection through surveys and interviews with teachers in England.

Table 1. Methods used, their benefits and limitations.

\begin{tabular}{|c|c|c|}
\hline Method & Summary of Method & Benefits and Limitations \\
\hline Literature review & $\begin{array}{l}\text { - } \quad \text { Key search terms } \\
\text { Peer-reviewed literature from the last five } \\
\text { years from a range of national contexts } \\
\text { Supplemented by knowledge within the } \\
\text { research team of relevant authors } \\
\text { and studies } \\
\text { Follow-up relevant literature from } \\
\text { references, particularly around definitions } \\
\text { of mid-career teachers }\end{array}$ & $\begin{array}{l}\text { Identifies key issues in existing research } \\
\text { evidence, including from systems } \\
\text { outside English education } \\
\text { - Suggests areas of disagreement and } \\
\text { gaps in knowledge } \\
\text { Rapid approach and focus on } \\
\text { anglophone studies means key } \\
\text { literature may be missed }\end{array}$ \\
\hline Secondary data analysis & $\begin{array}{l}\text { Descriptive statistics generated from } \\
\text { OECD TALIS } 2018 \text { teacher questionnaire } \\
\text { on job satisfaction and professional } \\
\text { development } \\
\text { - Associational regression models relating } \\
\text { professional development to } \\
\text { job satisfaction }\end{array}$ & $\begin{array}{l}\text { - Tests findings from literature review in } \\
\text { current national context } \\
\text { - } \quad \text { Rigorous data, but limited analysis }\end{array}$ \\
\hline Primary data collection & $\begin{array}{l}\text { Survey and focus groups of self-defined } \\
\text { mid-career teachers from across } \\
\text { school phases }\end{array}$ & $\begin{array}{ll}\text { - } & \text { Rapid, current understanding of issues } \\
\text { - } & \text { Tests findings from other methods } \\
\text { - } & \text { Self-selecting sample of participants }\end{array}$ \\
\hline
\end{tabular}

Further details of these methods are given below.

The scoping approach allowed us to be flexible in the sequencing of our methods: each method supplemented and informed the others in an iterative process of feedback, comparison and further analysis. This triangulation of data from three distinct methods provided rich evidence of findings across the knowledge base, enabling identification of 
areas of apparent agreement and disagreement, strengthening our emerging understanding from each data source. By using this mixed methods approach, the study builds on the methodological benefits of each approach while mitigating their inherent shortcomings. As is appropriate for a scoping study, the approach also supported the identification of gaps in the knowledge base and areas for further research.

\subsection{Literature Review}

Initial searches of the past five years of peer reviewed evidence, published in English, were carried out using pre-defined search terms and inclusion criteria (e.g., education systems similar to that of England, such as the other United Kingdom countries, anglophone jurisdictions and systems with high PISA rankings) in relevant databases. Initial search terms included: "mid-career teachers + CPD," "mid-career teachers + professional development" and "mid-career teachers + CPD + retention." These were applied in Google Scholar and educational databases. To supplement these searches, suggestions from colleagues were sought along with studies with which we were already familiar, and references were "snowballed" [46] as appropriate. Grey literature, such as reports produced by government and research organisations, was also included.

Our focus was on studies focussed on mid-career teachers and factors linked to their career progression, retention and professional development in England and other jurisdictions as above. As this was not intended to be a systematic review, we did not assess the strengths of studies, instead using them together as indicators of the nature of research activity in the area, thereby mapping key concepts, summarising emerging themes and identifying gaps [41]. The review of literature identified key areas of focus for secondary data analysis and primary data collection, and in turn, further analysis of the literature was informed by findings from these other methods.

\subsection{Secondary Data Analysis}

The OECD's Teaching and Learning International Survey (TALIS) is a large-scale international comparative study of teachers and school leaders that focuses on teachers' practices, working conditions and the learning environment in schools. Findings from TALIS are widely used for national and international analysis and comparison, justifications of research and initiatives, and in policy development [47-51].

The TALIS 2018 survey took the form of a 45-60 min online questionnaire for school leaders and teachers of pupils of "lower secondary" age (in England, 11-14 years old), carried out between March and May 2018. Our secondary data analysis used the 2316 teachers' responses from England. To identify mid-career teachers, drawing on initial findings from the literature review, we used a working assumption that they are those with 5-15 years' experience in the profession. There were 995 of these among the responses from teachers in England. The data generated descriptive statistics and correlations between mid-career teachers' job satisfaction and their professional development.

The sampling structure of TALIS clusters teachers within schools; teachers' responses were not independent. To account for that structure, the OECD provides replicate weights that enable the construction of accurate confidence intervals from the weighted sample. We used the weights wherever possible in our analysis. However, weights fit less naturally with some statistics. For example, the number of mid-career teachers in our sample was unweighted because the sample weighting did not include years of experience in its construction.

\subsubsection{Professional Development Indicators in TALIS}

The TALIS 2018 survey includes several composite indicators related to professional development [52], of which we used three (Table 2). This use of composite indicators avoided relying on single questions and meant that we did not have to develop and validate scales of our own. These individual questions were weighted using confirmatory factor analysis, and the latent variable was provided by the OECD as an indicator [52]. 
Each of the indicators are unitless and were rescaled to have a mean of zero and a standard deviation of one.

Table 2. Professional development indicators in TALIS used in this study.

\begin{tabular}{cl}
\hline Indicator & \multicolumn{1}{c}{ Related Question(s) } \\
\hline Effectiveness of professional development & The professional development activity that had the greatest \\
& positive impact on the respondent's teaching during the \\
previous 12 months: & - It built on my prior knowledge \\
& - It adapted to my personal development needs \\
& - It had a coherent structure \\
& It appropriately focused on content needed to teach \\
& my subjects
\end{tabular}

Respondent's need for professional development in subject matter and pedagogy in five areas:

Professional development needs

Barriers to professional development
- $\quad$ Knowledge and understanding of my subject field(s)

- $\quad$ Pedagogical competencies in teaching my subject field(s)

- Knowledge of the curriculum

- Student assessment practices

- Student behaviour and classroom management

The degree to which the respondent considers the following are present barriers to their participation in professional development:

- I do not have the prerequisites (e.g., qualifications, experience, seniority)

- Professional development is too expensive

- There is a lack of employer support

- Professional development conflicts with my work schedule

- I do not have time because of family responsibilities

- There is no relevant professional development offered

- There are no incentives for participating in professional development

\subsubsection{Indicators of Retention in TALIS}

In Jerrim and Sims' analysis of the 2018 TALIS findings for the English Department for Education [53], they found that attrition from the profession can be predicted by a composite indicator of teachers' satisfaction with their work environment. That indicator is composed from teachers' responses to four questions:

- I would like to change to another school if that were possible;

- I enjoy working at this school;

- I would recommend this school as a good place to work;

- All in all, I am satisfied with my job.

Therefore, in this study, we used this indicator as our central measure of job satisfaction and predictor of attrition. To supplement this, we used two additional latent measures provided by the OECD [52]:

- The OECD's composite measure of satisfaction with the teaching profession;

- The OECD's composite measure of overall satisfaction. This combines the measure of satisfaction with the work environment with the measure of satisfaction with the profession. It does not include new information beyond those two.

These indicators are, again, unitless latent variables constructed using confirmatory factor analysis. 


\subsection{Primary Data Collection}

To complement the literature review and secondary analysis of data, we carried out a small-scale survey and a series of focus groups with teachers working in England. Survey data was collected prior to COVID-19 restrictions in England; focus groups took place via videoconferencing during a period of limited access to schools for English pupils. The study received ethical approval from Sheffield Hallam University's research ethics committee (reference ER21486548), and all participants gave their informed consent for inclusion before they participated in the study.

Using convenience sampling, members of the Chartered College of Teaching, the professional body of teachers in England, were invited to complete the survey and participate in focus groups. Respondents were asked to self-identify as "mid-career teachers," in order that we could test teachers' perceptions of this stage of their career against findings from the literature.

Survey respondents (88 in total) had an average teaching experience of 14 years, with a range of 5-29 years. Nearly three quarters $(73 \%)$ had taken one to three career breaks, mostly due to parental leave, which lasted for around one year for the majority of participants. Three focus groups were carried out, including eight participants in total, who had an average teaching experience of 17 years (9-30 years).

The survey (Appendix A) drew on the outcomes of the literature review and the questions used in the secondary analysis for the three composite scores on teacher professional development. These questions were complemented further with questions focussed on issues including changes in job satisfaction over time, self-efficacy, autonomy, career progression, and retention. The focus groups used collated data from the survey as prompts for discussion.

The primary data sample was not representative of the whole teaching profession and did not seek to be, instead providing a current insight into teachers' lived experiences, which complemented the other methods. The majority of respondents to the survey taught in secondary schools (Appendix A), with the next largest group teaching in primary schools. This is unrepresentative of the number of teachers in England, which has roughly equal numbers of teachers working in primary and secondary schools [54], instead being more representative of membership of the Chartered College of Teaching. Eighty-four per cent of respondents were working full-time at the time of completing the survey and about half of those reported having caring responsibilities. The majority of respondents described themselves as female $(74 \%)$ and white British $(86 \%)$, which are both roughly representative of the English teaching workforce as a whole [54].

\section{Findings}

In this section, we present the findings from our study, starting with findings from the literature review on definitions of mid-career teachers. Next, we describe our findings from each of the three methods as they relate to teacher professional development and then to teacher retention and career progression, identifying similarities, differences, confidence and gaps in the results across the three approaches.

\subsection{Defining Mid-Career Teachers}

Mid-career teachers might be defined in a number of ways: through their years of experience, their professional role, their expertise and/or their dispositions to their role and practice. We begin our findings with a focus on the ways in which we can define and characterize mid-career teachers, exploring the literature which focuses on teachers progression and development through their careers, including models of teacher career stages and phases.

While there is a sizable body of literature around teachers' careers, which give varying definitions of career and life phases or stages, the term "mid-career" is generally not used. Instead, researchers have developed various models of teacher career phases or stages, which may be collectively known as the career cycle [16]. The most common of these 
is a five-stage model (Table 3), typically deriving from Huberman's study of teachers in Switzerland [55]. In these models, career stages are defined by broad categories of years of practice and by teachers' perceptions of themselves, their skills and confidence and their context.

Table 3. Overview of models of career and/or skill acquisition stages.

\begin{tabular}{|c|c|c|c|}
\hline Dreyfus [56] $^{1}$ & \multicolumn{2}{|c|}{ Huberman [55] } & \multirow{2}{*}{$\begin{array}{c}\text { Day et al. [57] } \\
\text { Launching a career: initial } \\
\text { commitment (easy or } \\
\text { painful beginnings) }\end{array}$} \\
\hline Novice & $\begin{array}{l}\text { Exploration: survival } \\
\text { and discovery }\end{array}$ & $1-3$ years of teaching & \\
\hline Advanced beginner & $\begin{array}{l}\text { Stabilisation: teachers choose } \\
\text { to commit to teaching or leave }\end{array}$ & $4-6$ years of teaching & $\begin{array}{l}\text { Stabilisation: find commitment } \\
\text { (consolidation, emancipation and } \\
\text { integration into peer group) }\end{array}$ \\
\hline Competent & $\begin{array}{l}\text { Experimentation/activism or } \\
\text { reassessment: teachers may } \\
\text { question their career choice }\end{array}$ & $7-18$ years of teaching & $\begin{array}{c}\text { New challenges, new concerns } \\
\text { (experimentation, } \\
\text { responsibility, consternation) }\end{array}$ \\
\hline Proficient & $\begin{array}{l}\text { Serenity: a "gradual loss in } \\
\text { energy and enthusiasm is } \\
\text { compensated for by a greater } \\
\text { sense of confidence and } \\
\text { self-acceptance" [55] }\end{array}$ & 19-30 years of teaching & $\begin{array}{l}\text { Reaching a professional plateau } \\
\text { (sense of mortality, stop striving } \\
\text { for promotion, enjoy or stagnate) }\end{array}$ \\
\hline Expert & $\begin{array}{l}\text { Disengagement: either with } \\
\text { serenity or disappointment } \\
\text { and bitterness }\end{array}$ & $31-40$ years of teaching & $\begin{array}{l}\text { The final phase (increased } \\
\text { concern with pupil learning and } \\
\text { increasing pursuit of outside } \\
\text { interests; disenchantment; } \\
\text { contraction of professional } \\
\text { activity and interest, } \\
\text { disengagement, serenity) }\end{array}$ \\
\hline
\end{tabular}

${ }^{1}$ Note that Dreyfus' skill acquisition categories do not map in terms of years onto Huberman's five career stages.

The second and third stages of the five-stage model appear to be most relevant to the professional lives of mid-career teachers. The third stage Huberman [55] calls "experimentation/activism" and Day et al. [57] "new challenges, new concerns." Within this stage, Huberman sees three interlinking "aspects" through which teachers may move:

- a teacher gains the confidence to experiment with the intention of increasing their impact;

- the teacher realises that there are barriers to experimentation and seeks to make changes in their context, by seeking promotion or becoming an "activist";

- the teacher, having become proficient, grows "stale" [58] (p. 34) and may seek new challenges.

Building on this work, Day and colleagues [58-60] identify, from their studies of teachers in England, six professional life phases, based on the number of years teaching, rather than skills or progression. In these models there are subgroups within the phases where individual teachers may take different paths.

In relation to mid-career teachers, Day [58] defines a "middle professional life phase" for those with 8-24 years' experience (Table 4). In the first part of this phase, some teachers may remain engaged while others may begin to lose motivation. Later, many teachers have additional responsibilities in school, and this, alongside rising levels of personal commitment, means that the management of work/life tensions requires substantial amounts of energy, which in turn has the potential to affect professional motivation, commitment and effectiveness. Three subgroups of teachers in this professional life phase were identified: 
Table 4. Mid-career teachers' middle professional life phase, adapted from Day [58].

\begin{tabular}{|c|c|c|c|}
\hline & Years in Teaching & Phase & Sub-Group \\
\hline \multirow[b]{2}{*}{ Middle professional life phase } & $8-15$ & $\begin{array}{l}\text { Managing changes in role and } \\
\text { identity: growing tensions and } \\
\text { Transitions }\end{array}$ & $\begin{array}{l}\text { (a) Sustained engagement } \\
\text { (b) Detachment/ loss } \\
\text { of motivation }\end{array}$ \\
\hline & $16-23$ & $\begin{array}{l}\text { Work/life tensions: challenges to } \\
\text { motivation and commitment }\end{array}$ & $\begin{array}{l}\text { (a) Further career advancement } \\
\text { and good } \\
\text { results have led to increased } \\
\text { motivation/commitment } \\
\text { (b) Sustained motivation, } \\
\text { commitment and effectiveness } \\
\text { (c) Workload/managing } \\
\text { competing tensions/ } \\
\text { career stagnation have led to } \\
\text { decreasedmotivation, } \\
\text { commitment and effectiveness }\end{array}$ \\
\hline
\end{tabular}

- $\quad$ teachers whose commitment and motivation increased;

- teachers who maintained existing levels of commitment, motivation and effectiveness, while coping with competing demands;

- teachers who struggled with these, leading to decreased levels of commitment and motivation and effectiveness.

These stage and phase models suggest linear progressions through a career, albeit with varying timescales and differences for individual teachers. This is not without critique (for example, [61-63]), since teachers may move between stages depending on "a variety of influences related to personal, professional, and organizational factors" [64]. Therefore, these models may fail to adequately acknowledge an "understanding of, and in, practice" [65] and how teachers' skills and knowledge become embedded into their professional practice over time.

However, Huberman [55] acknowledges that differing, non-linear paths may be taken through the stages. Different stages in a teacher's career may or may not relate directly to years of experience, and both "harmonious" and "problematic" trajectories (p. 38) are possible, in which teachers variously experience periods of stability, progression, regression and discontinuities. In this regard, career development might more helpfully be seen as a "process not a series of events" (p. 32).

Some linear models have also been criticised for not recognising that unexpected movement is possible, for example, when teachers choose to challenge existing ideas or initiate change [65]. Therefore, rather than progressing through time, teachers may develop their skills and practice in a non-linear fashion. Some teachers might deepen their understanding of a particular area of practice, such as working with children with special educational needs and disabilities, thereby increasing their specialist expertise in this area without necessarily increasing their range of practice. Others may develop their skills across a range of areas of practice. This recognises the importance of the teachers themselves and "the way in which professionals understand and perform their practice"... "which forms the basis for professional skill and its development" (p. 406).

Finally, the literature suggests that there is not necessarily a link between time spent in the profession and teaching expertise. As Maandag et al. [66] note: "the mere length of a career does not necessarily lead to the development of expertise and improved performance and not all teachers reach high levels of teaching quality in spite of lengthy careers" (p. 8). Indeed, it appears that some teachers become less effective later in their careers as they deal with the challenges of increased responsibility and commitments in and out of school $[59,66,67]$. While a teacher might have acquired high levels of skills after $5-7$ years, and competence a few years earlier, time and experience alone do not make an expert teacher. This highlights the need, which we shall return to later, for continuing professional development for teachers beyond the early years of their career.

In summary, from the literature review: 
- there is no agreed definition of a mid-career teacher;

- mid-career teachers are typically defined by their time in the profession, but there are intersections with wider life phases and the development of expertise;

- for at least some teachers, there is non-linear trajectory between and within career phases and career progression.

\subsection{Mid-Career Teachers' Professional Development}

Next, we consider the second research question: how might we categorise mid-career teachers' professional development needs and how do these relate to the professional development that is typically available to teachers? We look first at findings from the literature, then from our secondary data analysis and finally from the primary data collection.

\subsubsection{Literature}

There is an existing international body of work on the development needs of teachers at various career stages [68]. Professional development may play a significant role in reducing the numbers of teachers leaving the profession beyond the first five years of teaching [16]. The need for teachers, at all career stages, to engage in what Donaldson [24] calls "careerlong learning," and Day et al. [68] an "important professional life investment," "recharging batteries," or "renewal/refreshment" (p. 148), is widely accepted, as is a recognition that not engaging in professional learning could result in eventual disengagement and withdrawal from the profession [69]. However, there is little specific evidence on what constitutes effective professional development other than for teachers in the early stages of their career [66].

For all teachers, professional development opportunities and offers should be tailored to individual teachers' particular context and needs [16,34,62,70-72]. In common with other studies, Kyndt et al. [73] found that conditions both personal (e.g., motivation, autonomy, self-efficacy) and contextual (e.g., in-school support) are vital for professional development to be successful. Day and $\mathrm{Gu}$ [59] agree, noting the need for professional development to address the differing needs, influences and issues at different stages of teachers' professional lives, including motivation, commitment and outcomes. As Schwille [74], quoted in Bressman et al. [62], states: opportunities for professional development "must be substantive and relevant so that teachers connect to them" (p. 155).

Since professional learning can be influenced by multiple factors, including teachers' working environment, their professional identity and feelings of self-efficacy, home life and career ambitions [75], it seems likely that there may be key factors of relevance to mid-career teachers' professional development that differ from those for teachers at other career stages. For example, while teacher autonomy may increase during the first six years in the profession, it does not continue to increase unless a teacher moves into a managerial role [68], and a "substantial proportion of teachers report having little direction over how they intend to improve their practice and grow as professionals in future." Avidov-Ungar et al.'s study of Israeli teachers with over eight years' experience [70] found that compulsory professional development was unpopular, with teachers finding that it it was limited in scope and did not suit their needs..

Day and $\mathrm{Gu}$ [59] note that each of their six professional life phases (see above) requires tailored professional development, as teachers have differing needs and issues at different stages of their professional lives. For example, they describe the 8-15 years phase as a "key watershed or crossroads in teachers' professional learning and development" (p. 436), when it is vital to offer appropriate professional development because "more than in any other phases, [professional development] is likely to influence their final commitment and effectiveness trajectories" (p. 436). For these teachers, then, it is of particular importance to ensure that appropriate professional learning opportunities are available, particularly that which aims to lead to "enhanced ... effectiveness" (p. 437). For example, those who have aspirations towards leadership will have differing professional development needs from those who wish to stay as classroom teachers. For those struggling with their work/life 
balance, support could focus on "improving their self-efficacy, morale and emotional well-being" (p. 436).

Drawing on Huberman's career stages [55], described earlier, the mid-career teachers' "activist" drive to experiment, refine and diversify teaching skills, such as by combining classroom and management roles, has been recognised in other studies [73,76]. A challenge for those looking to support mid-career teachers may therefore be to consider how to effectively support teachers in moving from "stabilisation" to "experimentation," while ensuring that they do not grow "stale" and, as a consequence, choose to leave the profession. Interestingly, Day et al. [57] found that teachers with 8-15 years' experience rated professional development as more important than teachers at early or later career stages. For the next career stage (16-23 years of teaching), this study found that tensions around work/life balance become more significant, with increased leadership and management responsibilities at work potentially clashing with home lives and teachers feeling that their classroom effectiveness is at risk of compromise.

For those with caring responsibilities outside school and those who work part-time, the need for and access to professional development tailored to career stage may be particularly pertinent, and this may disproportionately affect women. Brown [77] highlighted inconsistencies in terms of access to paid professional development amongst women who worked part-time in England. In this study, an inconsistent approach was identified in terms of remuneration for women to attend professional development on days when they were not normally working; this included inconsistency in schools funding childcare whilst women were attending non-paid professional development.

In terms of the content of professional development for mid-career teachers, Louws et al.'s small-scale study [78] identified some differences in professional development preferences across career phases, with mid-career teachers more focussed on developing new areas of practice (including coaching, teaching children with special educational needs and curriculum development). The authors relate this to a desire to be challenged, motivated or to engage with new practice, which chimes with Huberman's "experimental" third career stage. In an earlier study [79], the same authors found that mid-career teachers showed less enthusiasm for learning about classroom management or learning climate than either early or late career teachers, perhaps due to a belief that they are sufficiently skilled in these areas.

Donaldson et al.'s study [80] concluded that those "second stage" teachers (defined as 3-10 years' experience) who take on "reform" roles-seeking to "change colleagues' practice" (p. 1089)—should engage in professional development to help them both promote their role and support them in encountering resistance in their context. Eros [16] notes that professional development for "second stage" teachers (defined as teachers in Huberman's "stabilization" phase of 4-6 years' experience) should emphasise topics beyond classroom teaching, moving towards leadership or wider contributions to teaching, such as in a family of schools, responding to local educational priorities, or to building new skills such as curriculum development. A study by Richter et al. [76] found that reading of professional literature, and interest in subject content, psychology and subject-specific pedagogies, increased towards mid-career. Avidov-Ungar et al. [70] found that 13 out of 14 advanced primary teachers (with 8-23 years' experience) were interested in "teaching-related courses" (p. 841) rather than those linked to management.

Experienced teachers appear to be more able to relate their learning to wider experiences of teaching than early career teachers [73]. Further, Mertler [81] identified that the chance to take part in "job-embedded, relevant, and ongoing professional development in the form of classroom-based action research" was rated more highly than other kinds of professional development by more experienced teachers (p. 44). Relating to this, Steffy et al. [69] suggest that professional development for experienced teachers could therefore include supporting others, through, for example, coaching of novice teachers, study teams and peer coaching. 
Summarising, it appears, from the literature and across various national contexts, that the professional development needs of mid-career teachers differ from those of early career teachers but that they may not be easily classified as a single group. Rather, mid-career teachers have varying professional development needs, based on their career trajectories and ambitions, their expertise, and wider personal and professional priorities and contexts.

\subsubsection{Secondary Data}

Compared with teachers in the early stages of their careers, mid-career teachers taking part in the TALIS 2018 survey reported a reduced need for professional development, increased barriers to professional development and, notably, that the professional development they engage in is less effective (Figure 1). The change from early career to mid-career is significantly larger than that from mid- to late-career. Mid-career teachers here are those with 5-15 years of experience, whereas early-career teachers are those with less than five years of experience, and teachers with more than fifteen years are described as "experienced."
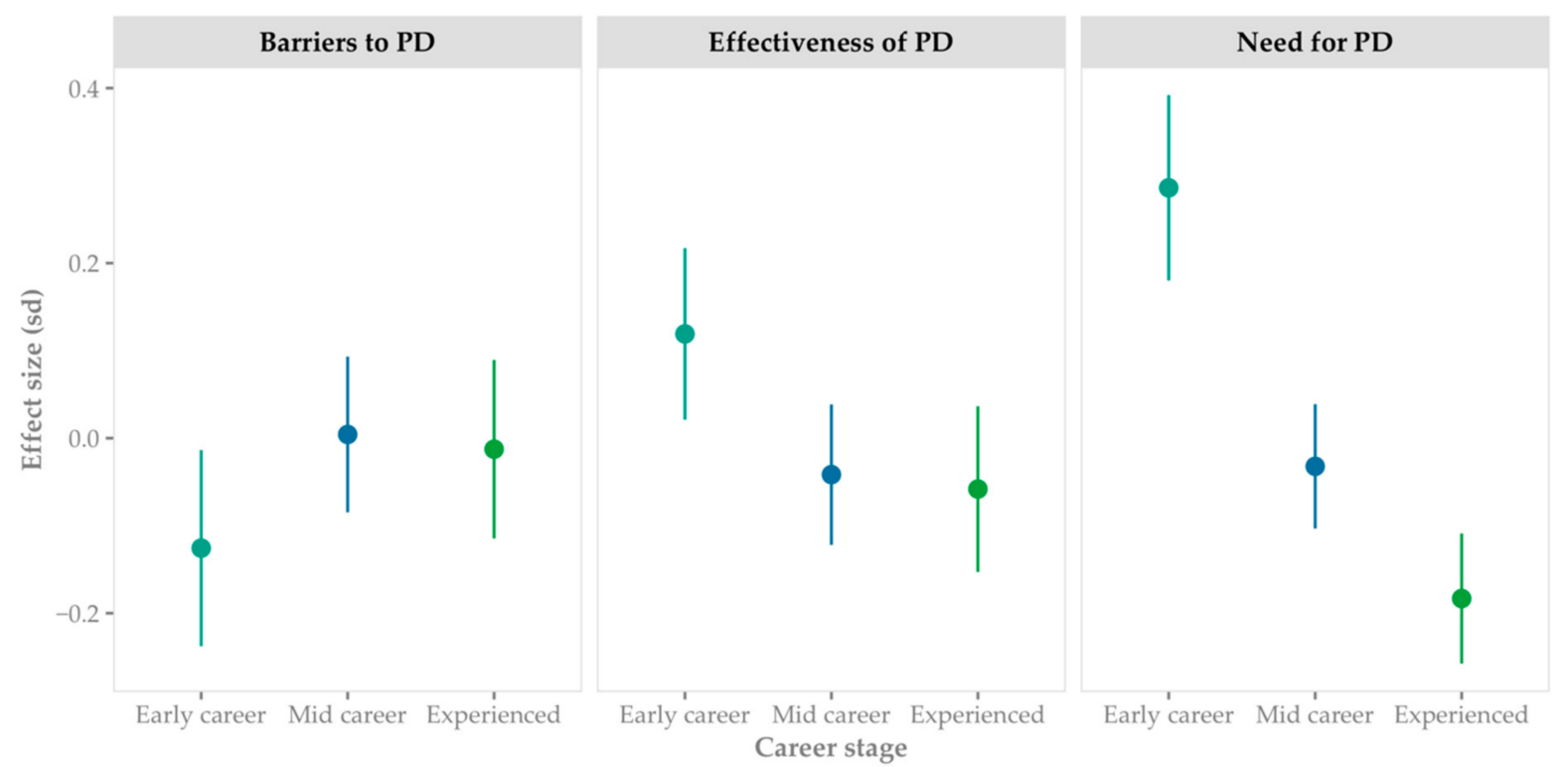

Figure 1. Teachers' experiences of professional development; source: TALIS 2018; note: weighted means and 95 per cent confidence intervals of the mean value, scaled and centred to a full-sample mean of zero and standard deviation of 1 .

The data also indicate that mid-career teachers undertake fewer hours of professional development than teachers in other career stages (Figure 2), which is perhaps an indicator of their perceived lack of need and/or its lack of effectiveness.

Even though they report participation in less professional development overall, midcareer teachers engage in broadly similar types and models of professional development to teachers at other career stages (Figure 3); although there do appear to be trends across teachers' careers. For example, as teachers gain experience, they appear to attend fewer courses, conferences and networking events in person. 


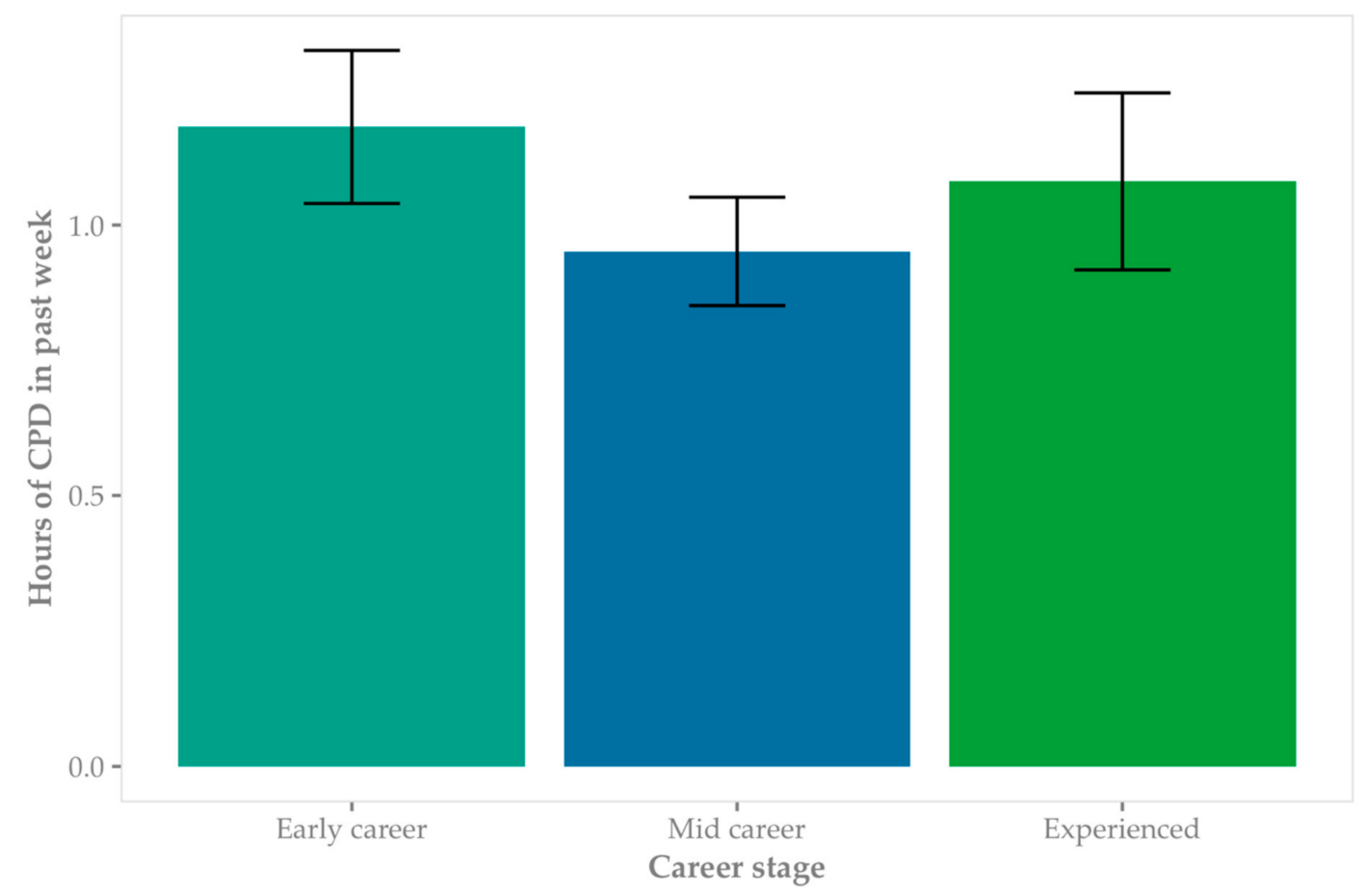

Figure 2. Teachers' time spent engaging in professional development; source: TALIS 2018; note: weighted means and 95 per cent confidence intervals of the mean value.

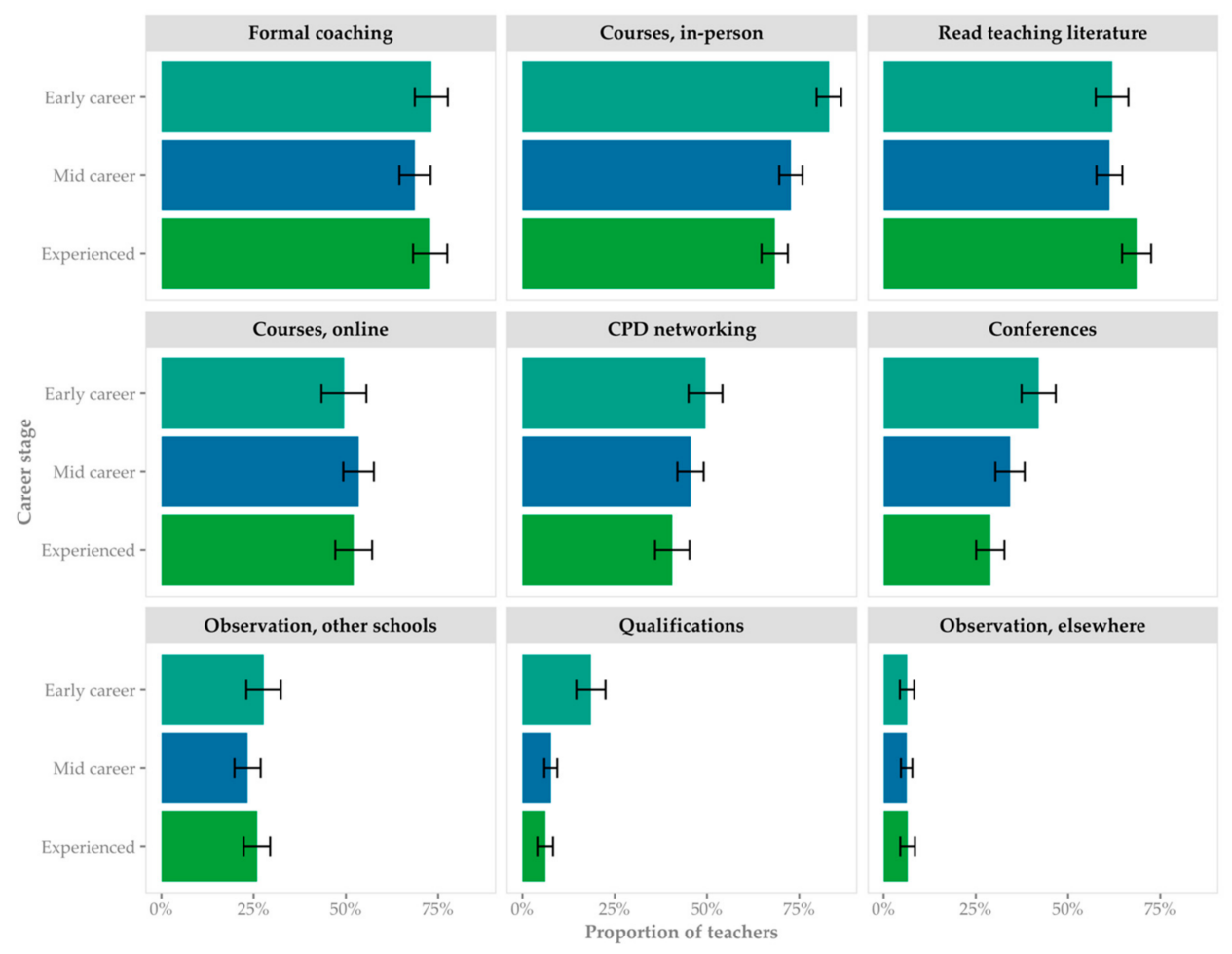

Figure 3. Teachers' engagement in different forms of professional development; source: TALIS 2018; note: weighted response to the question "during the last 12 months, did you participate in any of the following professional development activities?" Whiskers denote 95 per cent confidence intervals.

Reported barriers to professional development were roughly similar across career stages (Figure 4). In line with evidence from the literature, mid-career teachers reported conflicts with their work schedules and competing family commitments as greater barriers 
to participation, compared to teachers in other stages of their careers. It is possible that the increased scheduling difficulty contributes to the observed decline in in-person attendance at professional development events indicated above and the slight increase in online participation compared to early career teachers.

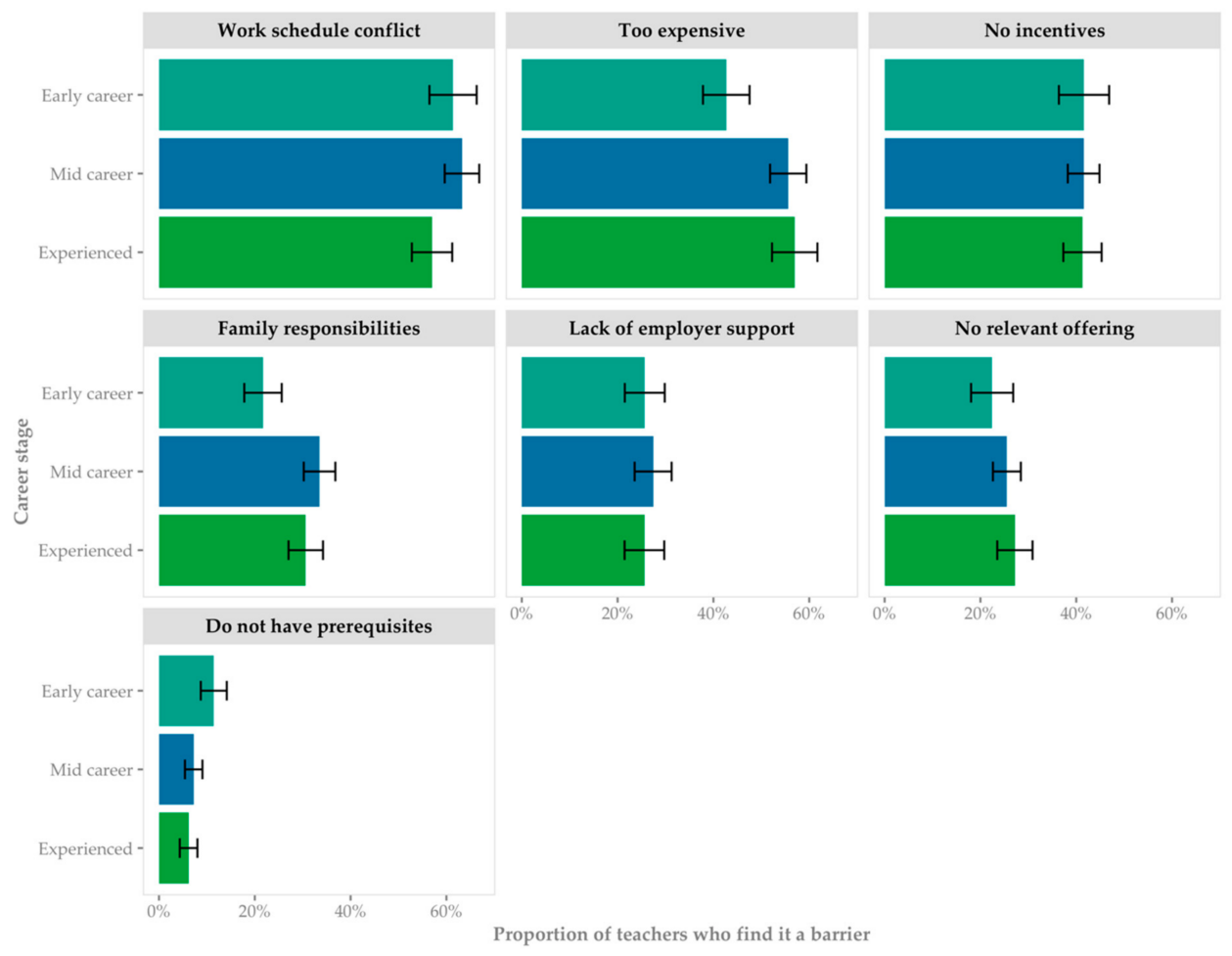

Figure 4. Teachers' reported barriers to participation in professional development; source: TALIS 2018; note: weighted proportion of respondents who agree or strongly agree that "the following present barriers to your participation in professional development?" Whiskers denote 95 per cent confidence intervals.

Looking at the data for mid-career teachers specifically and matching this to data about job satisfaction (using satisfaction with their work environment as a proxy for this) suggests that where these teachers experience more effective professional development, or when they perceive fewer barriers to this, they feel a greater degree of job satisfaction (Figure 5). The association is particularly strong for the latent variables representing barriers to professional development.

Quantifying the strength of the association using linear multiple regression confirmed its strength (Appendix B). The regression also showed the strength of the associations between mid-career teachers' professional development and job satisfaction to be indistinguishable from that of all teachers. It is possible that there is a distinction between mid-career and early-career teachers, but, from this data set, mid-career teachers were not significantly different from the average teacher participating in TALIS. 


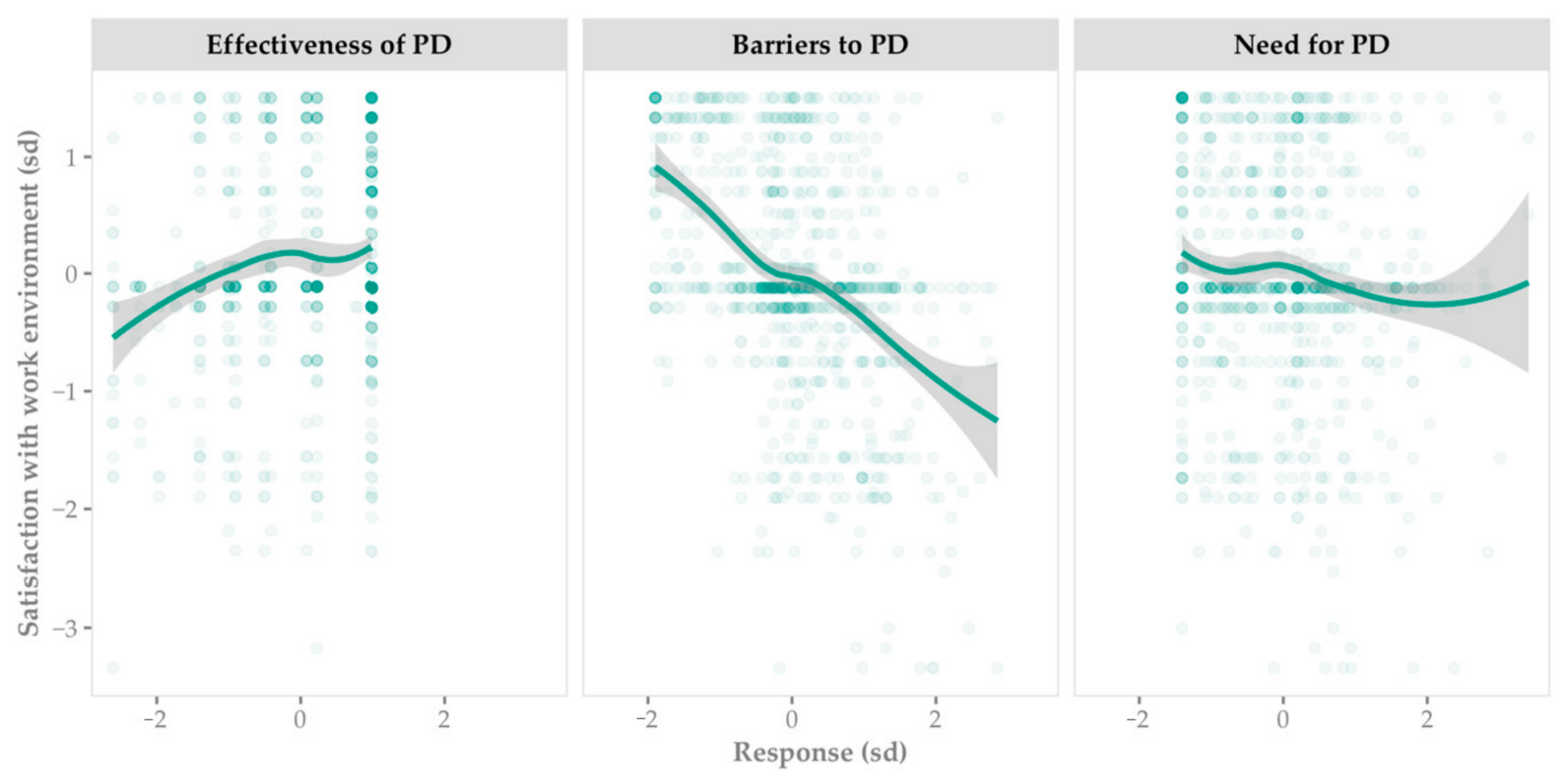

Figure 5. Mid-career teachers' experiences of professional development are correlated with job satisfaction; source: TALIS 2018; note: scatter of latent variables for aspects of professional development against latent variable for satisfaction with work environment. All variables centred and scaled. Loeoursss fit lines with 95 per cent confidence intervals.

\subsubsection{Primary Data}

Our primary data reveals mixed views about access to and quality of professional development for mid-career teachers. For example, whereas nearly half the participants $(49 \%)$ indicated (agree/strongly agree) that they have access to high-quality professional development professional development that supports them in their career, nearly the same proportion $(42 \%)$ felt that they did not. Meanwhile, most teachers in the survey reported participation in between five and 25 hours of professional development activities per academic year.

Over half of survey participants (54\%) felt that the professional development they had access to supported their professional development needs, contrasted with nearly $40 \%$ who felt that it did not. In focus groups, some regional, phase- and context-specific variations relating to the availability of professional development emerged. For example, teachers in the south-east of England, particularly London, and in government-designated "opportunity areas" [82] and university cities appeared to be more able to access professional development.

Survey respondents felt overwhelmingly that the professional development activities they participated in had a positive effect on their teaching $(80 \%)$, a finding which contrasts with that of the TALIS data above. Activities that built on teachers' prior knowledge were perceived to have the most impact (Table 5), a finding which indicates the importance of recognising mid-career teachers' experience and expertise in their professional development. 
Table 5. Survey responses: thinking of the professional development activities that had the greatest positive impact on your teaching during the last 12 months, did it have any of the following characteristics?

\begin{tabular}{ccc}
\hline CPD Feature & Percentage & 95\% CI \\
\hline It built on my prior knowledge & $83.33 \%$ & {$[73.33,93.33]$} \\
\hline $\begin{array}{c}\text { It provided opportunities to practise/apply new ideas and } \\
\text { knowledge in my own classroom }\end{array}$ & $56.25 \%$ & {$[46.25,66.25]$} \\
\hline $\begin{array}{c}\text { It took place over an extended period of time (e.g., several } \\
\text { weeks or longer) }\end{array}$ & $47.92 \%$ & {$[37.92,57.92]$} \\
\hline It focused on innovation in my teaching & $37.50 \%$ & {$[27.5,47.5]$} \\
\hline It provided opportunities for collaborative learning & $37.50 \%$ & {$[27.5,47.5]$} \\
\hline It had a coherent structure & $35.42 \%$ & {$[25.42,45.42]$} \\
\hline It provided opportunities for active learning & $31.25 \%$ & {$[21.25,41.25]$} \\
\hline It adapted to my personal development needs & $31.25 \%$ & {$[21.25,41.25]$} \\
\hline It appropriately focused on content needed to teach & $27.08 \%$ & {$[17.08,37.08]$} \\
\hline It took place at my school & $25.00 \%$ & {$[15.00,35.00]$} \\
\hline It provided follow-up activities & $20.83 \%$ & $12.50 \%$ \\
\hline It involved most colleagues from my school & {$[10.83,30.83]$} \\
\hline
\end{tabular}

In terms of barriers to participation in professional development, focus group participants noted that they often engaged in professional development outside working hours, at weekends or evenings, leading to conflicts with family and other commitments. Indeed, conflicting professional development and work schedules were considered by survey respondents to be the most significant barrier to attending professional development $(62 \%)$, followed by the cost of professional development and lack of incentives to attend. Supporting other findings, around a third of respondents felt that available professional development was not relevant to their learning needs, and that family responsibilities were a barrier to attending professional development. For the full set of responses to this question, see Appendix A.

Some participants highlighted a lack of access to professional development that was relevant to their career stage. As one participant phrased it: "once you're the expert, there aren't any other experts." Closer connections to higher education, either through initial teacher education or postgraduate study, were suggested as potential solutions to this issue. For example, two participants referred to their experience completing master's degrees and the Chartered Teacher programme [83] alongside teaching, suggesting that these experiences were beneficial by providing opportunities to engage with research, to reflect on practice and to conduct small-scale inquiries. In one school, teachers were supported to complete master's degrees by the provision of part-time contracts for the duration of study.

Views were also split regarding schools' prioritisation of professional development. Whereas $43 \%$ of survey respondents agreed or strongly agreed that, in their school, it was a priority to ensure that teachers have access to high-quality professional development, $41 \%$ disagreed or strongly disagreed with this. In focus groups, some participants described systems where professional development is woven into the school's fabric, with an offer described as personalised, regular and subject- and career-stage specific. However, other teachers described issues such as schools' priorities clashing with their own and lack of time away from the classroom to participate in professional development, especially the case for teachers with large numbers of examination classes. Whole-school professional development was not seen as particularly relevant to participants because it appeared to be either aimed at colleagues earlier in their career and/or lacked subject specificity. 
When asked how current professional development opportunities could be improved, the majority of responses referred to an increase in time allocated to professional development, more strategic planning, greater financial support and an offer extending beyond leadership development. They also mentioned increased flexibility, more bespoke offers that take teachers' subject specialism and their career stage into account, and the need to sustain professional development over time, so teachers are able to reflect on learning and develop their practice.

Some suggestions to improve the relevance of professional development programmes for mid-career teachers included: more professional development focused on teaching and learning and opportunities to combine postgraduate study with teaching, although some participants felt that such approaches may be easier towards the beginning of a teaching career when teachers tend to have fewer caring responsibilities. Further, it was suggested that coaching and mentoring could facilitate more personalised approaches to professional development, by enabling teachers to identify their goals and define their professional development priorities. In some schools, coaching and mentoring was common practice, sometimes combined with appraisals and performance management, but other schools did not offer any support for coaching or mentoring.

The need for more professional development opportunities outside the leadership track emerged from focus group discussions. Where participants reported high levels of job satisfaction, this appeared to relate to a strong school-led focus on professional development and high levels of autonomy in choosing professional development that related to their professional development needs. A majority of focus group participants emphasised that the system does not currently provide sufficient developmental opportunities for teachers who want to build their expertise in teaching, valuing their experience, rather than moving into leadership. This is illustrated in the following quote: "I'm teaching eight years now. I think after five years, teachers should be given funded or partially funded courses to go back into the research about education: time within schools to complete these courses. More work on the different pathways. I'm a second-in-department, and my traditional next step is to become a head of department, which I don't want."

Teachers' autonomy in shaping their own professional development emerged as another issue with mixed responses. Thirty-five percent of survey respondents indicated that they have little or no autonomy in choosing their professional development, contrasted with $48 \%$ who indicated that they have at least some level of autonomy in choosing their professional development. The need for more autonomy in choosing professional development was highlighted in focus group discussions, illustrated by this quote: "they would need to directly address my own personally-directed needs and wants for myself as a teacher: I know where and what I want to develop." Those participants who had more autonomy in choosing professional development were able to choose opportunities that were most relevant to them, were given time to read literature that they found to be helpful, were engaged in coaching or visited other schools.

These findings suggest that mid-career teachers, represented here by the participants in our primary data collection, have varying experiences of professional development, which appear to be influenced, at least in part, by their school contexts. To improve access and engagement, some possible actions include more flexible participation, better targeting of professional development in relation to teachers' career stages, and opportunities for professional learning outside leadership development.

\subsection{Mid-Career Teachers' Retention and Career Progression}

We end the findings by looking at the third research question: can we identify common factors relating to the retention and career development of mid-career teachers, and, if so, what are they? Again, we firstly consider findings from the literature, then from the secondary data analysis and finally from our primary data collection. 


\subsubsection{Literature}

Based on the career stage models described earlier, it is likely that the reasons for mid-career teachers leaving the profession differ from those earlier in their professional lives. For example, there appears to be a group of teachers in the "middle professional life phase" [58] who may begin to lose motivation. Mertler's study of teachers in Arizona [81] showed that, in general, teachers with greater experience in the profession had higher levels of dissatisfaction with their jobs and therefore were at higher risk of leaving. The author concluded that "it is quite likely that Arizona's teachers are satisfied with the work that they perform, but not with the recognition they receive" (p. 43), particularly around the issue of pay. On the other hand, some mid-career teachers feel that they have already made a substantial commitment of time and energy to the profession and gained a significant amount of profession-specific knowledge [61]. It is not clear whether this increased "professional capital" makes teachers more likely to stay in the profession, although Borman and Dowling's meta-analysis of US studies of teacher attrition [61] found that "there is somewhat more evidence suggesting that it is the more talented rather than the less talented teachers-those who are better trained, more experienced, and more highly skilled-who tend to be lost to turnover with greater frequency" (p. 396).

A lack of autonomy, for example, around professional development or career progression, has been suggested as a reason why experienced teachers choose to leave the profession [16]. Further, as we have discussed above, experienced teachers may feel discouraged when their development needs are ignored [35], and, arguably more than teachers in other career stages, they may seek opportunities to work flexibly and may require support in balancing competing priorities. If these are unavailable, they may choose to leave the profession.

After five years in the profession, teachers are in Huberman's "stabilisation" phase, where they choose to commit to teaching or leave, and, if taking the former route, may be looking beyond the classroom to build a long-term career in teaching [59]. However, in practice, teachers are often not given a clear progression route in their careers. For example, there tend to be few opportunities for promotion [73] and, in any case, as we have seen already, not all teachers wish to take on leadership roles [24]. Therefore, in order to retain and support teachers in their second or third career stages, schools must develop "new pathways for these seasoned educators to flourish" (p. 168) [62]. In an English context, Worth et al. [84] agree, stating that "alternative career pathways which keep good teachers teaching, rather than taking up management positions" (p. 14) might offer a route to improved retention.

Coldwell [28] noted a link between satisfaction, efficacy and retention in earlier literature, stating there is "evidence of a relationship between efficacy and intention to stay in the profession such as Brouwers and Tomic (2000) that showed that higher selfefficacy was related to lower levels of teacher 'burn out' on a range of measures, and other reviews link efficacy to teacher retention, again with generally weak relationships found (Tschannen-Moran, Woolfolk Hoy \& Hoy, 1998; Klassen, Tze, Betts \& Gordon, 2011). They also suggest that we might usefully focus our attention on secondary teachers, where the greatest effects are found, and where job satisfaction is lower and attrition is higher." Meanwhile, analysis of the 2013 TALIS survey [85] found that "increased levels of effective professional development are associated with a reduced desire for teachers to move schools. More specifically, a one SD improvement in effective professional development is associated with a large, $63 \%$ reduction in the odds that a teacher wants to move to another school. This is almost as strong as the association with leadership quality" (p. 38).

Subsequent analysis in England linked data on teachers' attrition to questions in the TALIS 2018 survey about job satisfaction [53]. This found that secondary school (11-18) teachers have lower job satisfaction than primary (4-11) teachers and are, consequently, more likely to leave their jobs. It also found that the quality of leadership in the school has a strong association with job satisfaction and the chances that a teacher will leave the profession. While these findings are not specific to mid-career teachers, they illustrate 
how variations in job satisfaction provide a proxy measure of the probability of leaving the profession.

Overall, in common with findings described above, the literature here points towards mid-career teachers as a heterogeneous group, with varying experiences, levels of commitment and job satisfaction and motivations. These can be limited by a lack of opportunities for progression that meet teachers' aspirations for their career development.

\subsubsection{Secondary Data}

Turning to our secondary analysis of TALIS 2018 data, teachers' satisfaction with the work environment was fairly constant across career stages (Figure 6), and once teachers are beyond the early stages of the career so is their overall satisfaction with the profession. There appears to be little difference here between mid-career teachers and other experienced teachers, suggesting that other elements of the working environment contribute to teachers' job satisfaction in addition to experience. There is wide variation in job satisfaction among teachers, but very little is related to the teacher's career stage. The variation within career stages is far greater than the variation across career stages. It should be noted that the measure of job satisfaction is standard deviations from the overall average level of satisfaction, and so it describes only relative levels of job satisfaction between the groups and says nothing about the absolute level of satisfaction.

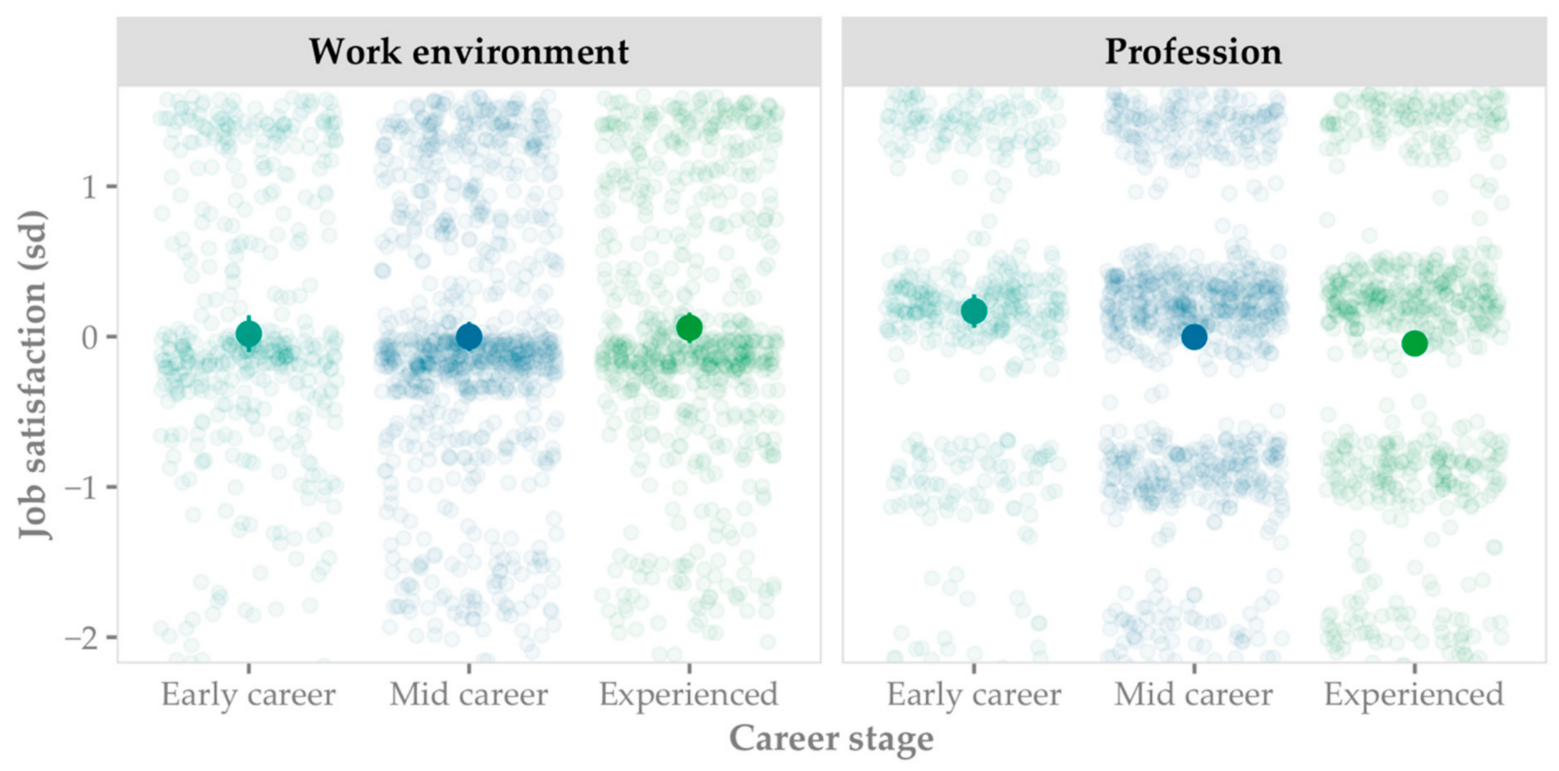

Figure 6. Teachers' satisfaction with their work environment and profession by career stage; source: TALIS 2018; note: background points are an unweighted scatter of individual respondents' satisfaction with their work environment and profession; both latent variables, centred and scaled. Large points in the foreground are the weighted means of those variables with 95 per cent confidence intervals denoted by whiskers.

\subsubsection{Primary Data}

Overall, respondents to the online survey displayed high levels of job satisfaction. The majority of respondents $(62 \%)$ agreed or strongly agreed with the statement that they were satisfied with their job, although nearly a quarter of respondents $(24 \%)$ were not satisfied. Interestingly, over half $(57 \%)$ of the respondents indicated greater satisfaction now than at the start of their career, although nearly one third $(29 \%)$ indicated that their job satisfaction was lower now than at the beginning of their career. This may be reflective of the evidence from the literature of the varying, individualised routes teachers take through their career stages.

Drawing on Day and Gu's descriptions of teachers' professional life phases [60], the survey included questions in which teachers rated their self-efficacy relating to various 
aspects of their practice (Appendix A). Overall, respondents reported very high levels of self-efficacy, especially in the areas of teaching and learning. With participants in the survey reporting both high levels of job satisfaction and high levels of self-efficacy, these findings support positive correlations shown in other studies (for example, [85]).

Given these high levels of job satisfaction and self-efficacy, it is surprising that a large majority of survey respondents $(86 \%)$ indicated that they had considered leaving the teaching profession at some point in their career, and nearly half $(44 \%)$ of respondents indicated that they were considering leaving the profession at the time of completing the survey. However, our findings also indicated that this group of teachers is not planning an imminent departure from teaching.

A lack of relevant professional development opportunities, as discussed above, appears to be an important factor in teacher retention here, with a majority of respondents $(57 \%)$ saying that a better professional development offer would encourage them to stay in the profession and help to keep them motivated and interested in teaching. As one survey respondent put it: "CPD [continuing professional development] is vital to teacher retention. Without innovative, forward thinking, exciting CPD, teaching could become a 'job' rather than a 'profession.'”

The lack of relevant professional development also appears to be a barrier to teachers' career progression. The majority of survey respondents (53\%) felt that the professional development they participated in was not relevant to the next step in their careers. During focus group discussions, it emerged that, for some teachers, the order of professional development and career progression can sometimes be inverted, with teachers being promoted to leadership roles before completing related professional development. Interestingly, participants felt that expert teaching was not sufficiently rewarded in comparison to managerial roles, when the opposite should be the case or they should, at least, be equally rewarded.

As we saw in the literature review, parental leave and family commitments were highlighted by several female participants as obstacles to career progression. A lack of flexibility in middle and senior leadership roles (such as opportunities for part-time working and/or job sharing) could hinder teachers with caring responsibilities to progress in their careers. The workload associated with these roles was further mentioned as being incompatible with family commitments, leading three participants to consider moving into higher education, based on a perception of this allowing for more flexible work arrangements.

These findings suggest that, even though teachers' job satisfaction may increase with experience, opportunities for flexible, individualised engagement in careers and professional development are not consistently available to mid-career teachers. While the impact of this is not clear, in the long-term, it may lead to dissatisfaction and influence the likelihood of teachers' retention in the profession.

\section{Discussion and Conclusions}

In this study we aimed to identify, through a scoping study, the ways in which mid-career teachers might be defined or categorised, thereby to better understand their professional development, career development and retention in the profession and to identify questions for further research. We took a purposefully rapid - and therefore inevitably partial—approach, aiming to explore current understanding in the literature, from existing data and from practitioners. In places, our findings were complementary; in others, they did not fully support each other. As mentioned in the introduction, the bulk of this study took place before restrictions relating to COVID-19 were implemented in England, and so, if a further review of the literature and/or primary data collection were conducted now, our findings might take a different shape.

In this section, we bring together the findings described above, referring back to our research questions, in order to explore what we can learn from this study and what further research might be valuable.

Turning first to the ways in which mid-career teachers might be defined and categorised, we considered whether this group can be identified in terms of years in the 
profession, professional role or expertise. We took different approaches to this: examining the literature to identify categorisations from previous studies, using a working definition based on years of experience for the secondary data analysis and enabling self-identification in the primary data collection.

The literature indicates that there is no widely accepted definition of what constitutes a "mid-career teacher." However, there is some agreement that teachers enter a "second stage" of teaching between around three or four and ten years in the profession. This period of teachers' professional lives, which follows the early career stage, covers, from the literature, Huberman's stabilisation and experimentation/activism or reassessment phases [55]; the advanced beginner and competence stages from Dreyfus [56]; the stabilisation and new challenges, new concerns stages from Day et al.'s five career stages [57]; and, from Day and $\mathrm{Gu}$ [60], the second part of the early professional life phase and the first part of the middle professional life phase. Therefore, for the secondary data analysis, we tested a definition of mid-career teachers as those with between five and fifteen years' experience. We found that this broadly aligned with the years of experience of those who self-identified as mid-career teachers in the primary data collection, suggesting that teachers enter what might be called their "mid-career" after around five years in the profession.

Focusing on whether mid-career teachers might be categorised in other ways, we identified some similarities in this group of teachers. Specifically, a key characteristic of mid-career teachers is the management of competing priorities and different aspects of professional and personal lives. This is brought about by a lack of time caused by the pull between family and work, and, for many, a lack of attractive development opportunities outside a "traditional" route to leadership.

Overall, mid-career teachers appear to be a less homogeneous group than early career teachers, who have relatively consistent development needs as beginning practitioners, although with individual and contextual variation related to subject, phase, school and individual needs and aspirations [29]. Mid-career teachers enter and leave this phase of their career in differing ways, with diverse professional experiences, varying trajectories within the phase, and changing priorities. These depend on a variety of factors including teachers' professional contexts and opportunities for development and progression and their own attitudes, beliefs and personal lives. Therefore, in order to better understand the retention and professional development of mid-career teachers, we need to consider their experiences, aims, interests and priorities, both within and outside work [14]. These are dynamic, varying over time alongside the ongoing development of expertise and/or changing professional or personal contexts.

This leads us to consider the second research question, on the professional development needs and experiences of mid-career teachers and whether or how these differ from those of other teachers. There are few studies that focus specifically on the development needs of mid-career teachers, other than those relating to school and subject leadership, which — as we have seen-mid-career teachers may not necessarily see as attractive development options. Teachers in the mid-career stage appear, from our primary data collection, to feel confident in their classroom practice and may perceive a lower need for some forms or types of professional development, compared to early career teachers. This may indicate a different set of professional development needs or indicate, as we have seen in our study, a lack of opportunities to develop in their contexts, and this may be linked to the correlation between teaching experience and decreased participation in in-person courses. Further, to these teachers, the concept of career progression can appear to be overly focussed on leadership roles rather than the further extension and development of expertise, practice or specialist interests.

However, as already noted, mid-career teachers are a heterogeneous group; in fact, our findings suggest that between-group differences (such as those between early career teachers and mid-career teachers) are smaller than differences between those in the midcareer group. Mid-career teachers as a group have varied, complex experiences and, importantly, differing — and dynamic — aspirations for their careers. This firstly means 
that their professional development needs are varied, based on individual ambitions, motivations, expertise, circumstances and wider life orientations. The ways in which midcareer teachers choose or opt to participate in professional development activities are also likely to differ. For example, some teachers may wish to develop through formal, accredited postgraduate routes; others through inquiry-led approaches. Competing priorities between work and home lives mean that opportunities should also be offered in ways that are flexible and adaptable. There is a need to identify and recognise the individual needs of mid-career teachers, the types and areas of potential development needs, and to acknowledge that these are dynamic and as such may change over time or context.

The final research question relates to the retention of mid-career teachers. Workload is the most commonly cited reason for leaving the profession for teachers across career stages [14]. Looking across our three methods, we found that for mid-career teachers, workload plays a significant role, both in relation to retention directly and indirectly as a factor that restricts engagement in professional development. This is in line with earlier work developing "path models" [86] and sits alongside other factors specific to this group of teachers. In particular, our sources of data agree that competing priorities, particularly a lack of time caused by a pull between family and work, are key characteristics of mid-career teachers. This suggests that supporting mid-career, and indeed all, teachers to manage their workload, through flexible models of working, career progression and professional development opportunities, may increase retention. Interestingly, in England, the Department for Education has recently announced an initiative to promote flexible working for teachers [87].

Looking at job satisfaction, as a measure of potential retention in the profession, our findings suggest that for many teachers beyond the early stages of their careers, job satisfaction is relatively high: the secondary data analysis shows that teachers beyond the early stages of their career have the highest levels of job satisfaction, and, in our primary data collection, a majority of respondents indicated greater job satisfaction in their midcareers than in its early stages. The literature review suggests that for some teachers, there are signs of increased or maintained commitment and professional skills gained through experience ("professional capital"). Increased autonomy is generally perceived to be a positive aspect of increased experience, leading to greater job satisfaction, and a lack of autonomy appears to contribute to demotivation and lower satisfaction. However, our findings suggest that, for some teachers, increased autonomy can lead to a feeling of being left unsupported, with limited availability of opportunities for development or progression.

Taken together, our findings suggest that mid-career teachers are a group of teachers that are easily overlooked: largely committed, skilled and intending to stay in the profession, but often feeling undervalued, juggling competing priorities and lacking opportunities for development. Further, we can see, although with somewhat lower confidence, that within the group of mid-career teachers there are variations in professional development needs, career trajectories and aspirations and levels of commitment to the profession.

Therefore, considering how policy makers might support mid-career teachers, and to open up possibilities for further investigation, we tentatively propose four broad, and potentially overlapping, groups of mid-career teachers:

- Career climbers: those moving up the traditional career ladder to leadership roles;

- Satisfied stalwarts: largely satisfied, often skilled practitioners, committed to the profession, without the intention to develop their careers in terms of leadership roles or awareness of how to do so;

- Family focussers: those maintaining, or trying to maintain, a dual focus on family life and career;

- Dissatisfied stayers: those that see little alternative to teaching, with few career ambitions and dissatisfaction with their role.

Our findings suggest that teachers move between these groups as their careers, personal lives and contexts change and that these trajectories may be influenced by the support they receive. Meanwhile, each of these groups, and those of multiple subgroups within 
them, is likely to have different development and learning needs, based on their experience, interests, motivations and working patterns. With this in mind, effective models of development should be based on the identification of particular learning needs, should build on and recognise teachers' expertise and should provide attractive progression routes that look beyond leadership opportunities. At a policy level, flexible models of working and of development, such as the English Department for Education's Specialist NPQs [33], appear to be potentially valuable opportunities to support mid-career teachers. A further avenue to consider is the potential for a career and/or progression framework for teachers beyond the early stages of their careers, so that varying career development routes are available and valued.

Given the nature of this project as a scoping study, inevitably these suggestions are tentative and require further consideration. Therefore, potential lines of research to meet the gaps in the research evidence include the following:

- investigate the four proposed groupings of mid-career teachers via primary research;

- examine different models of in-school support including flexible working and development models;

- further examine the relationships between development and support models and retention and/or career satisfaction of mid-career teachers.

To conclude, this scoping study indicates that mid-career teachers are a heterogeneous group who would benefit from an environment that is supportive in terms of professional development, flexible in terms of balancing competing priorities and that offers help with identifying opportunities for learning without being overly directive. This type of environment will offer teachers autonomy and agency in identifying their own areas for learning and where they choose to spend their time and effort in terms of professional development or other activities that they feel to be of benefit professionally. We offer some suggestions to enable this to happen. In order to provide the most appropriate support, and therefore for the profession to benefit most from this group of teachers, further rigorous research following the lines of enquiry developed in the scoping study is required.

Author Contributions: Data curation, J.B., M.C., L.-M.M. and J.Z.; Formal analysis, L.-M.M. and J.Z.; Funding acquisition, J.B., M.C., L.-M.M., E.P. and J.Z.; Methodology, J.B., M.C., L.-M.M., E.P. and J.Z.; Project administration, E.P.; Validation, J.Z.; Visualization, J.Z.; Writing—original draft, J.B., M.C., L.-M.M., E.P. and J.Z.; Writing-review \& editing, J.B., M.C., L.-M.M., E.P. and J.Z. All authors have read and agreed to the published version of the manuscript.

Funding: This study was funded by Sheffield Hallam University's allocation from the Research England QR Strategic Priorities Fund 2020.

Institutional Review Board Statement: The study received ethical approval from Sheffield Hallam University's research ethics committee (reference ER21486548, approved January 2020).

Informed Consent Statement: Informed consent was obtained from all subjects involved in the study.

Data Availability Statement: The secondary data presented in this study are openly available from the OECD at https:/ / www.oecd.org/education/talis/talis-2018-data.htm (accessed on 15 June 2021).

Acknowledgments: The authors acknowledge the contribution of Suzanne Brown to the original review of literature.

Conflicts of Interest: The authors declare no conflict of interest.

\section{Appendix A. Primary Data Collection}

Survey Questions

Job Satisfaction

Please indicate how far you agree with the following statements. 


\begin{tabular}{|c|c|c|c|c|}
\hline & strongly agree agree & $\begin{array}{l}\text { neither agree nor } \\
\text { disagree }\end{array}$ & disagree & strongly disagree \\
\hline \multicolumn{5}{|l|}{$\begin{array}{l}\text { Overall, I am satisfied } \\
\text { in my job. }\end{array}$} \\
\hline $\begin{array}{c}\text { Overall, I am more } \\
\text { satisfied in my job now } \\
\text { than I was at the start } \\
\text { of my career. }\end{array}$ & & & & \\
\hline
\end{tabular}

\section{Self-Efficacy}

Please indicate below how far you agree with the following statements.

\begin{tabular}{|c|c|c|c|c|c|}
\hline & strongly agree & agree & $\begin{array}{l}\text { neither agree nor } \\
\text { disagree }\end{array}$ & disagree & strongly disagree \\
\hline \multicolumn{6}{|l|}{ I can control disruptive behaviour. } \\
\hline \multicolumn{6}{|l|}{$\begin{array}{l}\text { I can calm a student who is disruptive } \\
\text { or noisy. }\end{array}$} \\
\hline \multicolumn{6}{|l|}{ I can help students to value learning. } \\
\hline \multicolumn{6}{|l|}{$\begin{array}{l}\text { I can formulate good questions for } \\
\text { my students. }\end{array}$} \\
\hline \multicolumn{6}{|l|}{$\begin{array}{l}\text { I can get students to follow } \\
\text { classroom rules. }\end{array}$} \\
\hline \multicolumn{6}{|l|}{$\begin{array}{l}\text { I can get students to believe that they can } \\
\text { do well in school. }\end{array}$} \\
\hline \multicolumn{6}{|l|}{$\begin{array}{c}\text { I can establish a classroom management } \\
\text { system with each group of students. }\end{array}$} \\
\hline \multicolumn{6}{|l|}{$\begin{array}{l}\text { I can use a variety of } \\
\text { assessment strategies. }\end{array}$} \\
\hline \multicolumn{6}{|l|}{$\begin{array}{l}\text { I can provide alternative explanations or } \\
\text { examples when students are confused. }\end{array}$} \\
\hline \multicolumn{6}{|l|}{$\begin{array}{l}\text { I can assist families in helping their } \\
\text { children do well in school. }\end{array}$} \\
\hline $\begin{array}{l}\text { I can implement alternative teaching } \\
\text { strategies in my classroom. }\end{array}$ & & & & & \\
\hline
\end{tabular}

\section{CPD}

Please indicate how far you agree with the statements below.

\begin{tabular}{|c|c|c|c|c|}
\hline & strongly agree agree & $\begin{array}{c}\text { neither agree nor } \\
\text { disagree }\end{array}$ & disagree & strongly disagree \\
\hline \multicolumn{5}{|l|}{$\begin{array}{c}\text { I have access to high-quality } \\
\text { CPD which supports me in } \\
\text { my career. }\end{array}$} \\
\hline \multicolumn{5}{|l|}{$\begin{array}{c}\text { Ensuring teachers have access } \\
\text { to high-quality CPD is a } \\
\text { priority in my school. }\end{array}$} \\
\hline \multicolumn{5}{|l|}{$\begin{array}{l}\text { The CPD I participate in } \\
\text { supports my individual } \\
\text { development needs. }\end{array}$} \\
\hline $\begin{array}{l}\text { I have autonomy in choosing } \\
\text { CPD that is relevant to me. }\end{array}$ & & & & \\
\hline
\end{tabular}


Have you done any of the following? Please tick all that apply.

- $\quad$ acted as a mentor for ITE [initial teacher education] students

- $\quad$ acted as a mentor for newly qualified teachers

- taken on a leadership role in your school

- taken on a leadership role across a wider group of schools

In the last 12 months, did you participate in any of the following professional development activities? Tick all that apply.

- Courses/seminars attended in person

- Online courses/seminars

- Education conferences where teachers and/or researchers present their research or discuss educational issues

- Formal qualification programme (e.g., degree)

- Observation visits to other schools

- Observation visits to business premises, public organisations or non-governmental organisations

- Peer and/or self-observation and coaching as part of a formal school arrangement

- Participation in a network of teachers formed specifically for the professional development of teachers

- $\quad$ Reading professional literature

- $\quad$ Other (please specify)

For the professional development in which you participated in the last 12 months, did you receive any of the following? Please tick all that apply.

- Release from teaching duties for activities during regular working hours

- Non-monetary support for activities outside working hours (e.g., reduced teaching time, days off, study leave)

- Reimbursement or payment of costs

- Materials needed for the activities

- Monetary supplements for activities outside working hours

- Non-monetary rewards (e.g., classroom resources/materials, book vouchers, software/apps)

- Non-monetary professional benefits (e.g., fulfilling professional development requirements, improving my promotion opportunities)

- $\quad$ Other (please specify)

- Increased salary

Thinking of all the professional development activities during the last 12 months, did any of these have a positive impact on your teaching practice?

- Yes

- No

Thinking of the professional development activities that had the greatest positive impact on your teaching during the last 12 months, did it have any of the following characteristics?

- It built on my prior knowledge

- It adapted to my personal development needs

- It had a coherent structure

- It appropriately focused on content needed to teach my subjects

- It provided opportunities for active learning

- It provided opportunities for collaborative learning

- It provided opportunities to practise/apply new ideas and knowledge in my own classroom

- It provided follow-up activities

- It took place at my school 
- It involved most colleagues from my school

- It took place over an extended period of time (e.g., several weeks or longer)

- It focused on innovation in my teaching

Approximately how many hours of CPD do you participate in, on average, per academic year?

- $0-5$

- $5-25$

- $26-50$

- $\quad$ over 50

How strongly do you agree or disagree that the following present barriers to your participation in professional development?

\begin{tabular}{|c|c|c|c|c|c|}
\hline & strongly agree & agree & $\begin{array}{l}\text { neither agree nor } \\
\text { disagree }\end{array}$ & disagree & strongly disagree \\
\hline \multicolumn{6}{|l|}{$\begin{array}{l}\text { I do not have the pre-requisites } \\
\text { (e.g., qualifications, } \\
\text { experience, seniority) }\end{array}$} \\
\hline \multicolumn{6}{|l|}{$\begin{array}{l}\text { Professional development is too } \\
\text { expensive }\end{array}$} \\
\hline \multicolumn{6}{|l|}{$\begin{array}{l}\text { There is a lack of support from } \\
\text { my school leaders }\end{array}$} \\
\hline \multicolumn{6}{|l|}{$\begin{array}{l}\text { Professional development } \\
\text { conflicts with my work schedule }\end{array}$} \\
\hline \multicolumn{6}{|l|}{$\begin{array}{l}\text { I do not have time because of } \\
\text { family or other responsibilities }\end{array}$} \\
\hline \multicolumn{6}{|l|}{$\begin{array}{l}\text { There is no relevant professional } \\
\text { development offered }\end{array}$} \\
\hline $\begin{array}{l}\text { There are no incentives for } \\
\text { participating in } \\
\text { professional development }\end{array}$ & & & & & \\
\hline
\end{tabular}

What are your professional learning and development priorities for the next couple of years?

What could be improved about the current CPD offer in your school to better support you in your career?

\section{Career Progression}

How would you rate your career progression so far?

- Much better than expected

- Better than expected

- As expected

- Worse than expected

- Much worse than expected

Please elaborate on your choice above.

How far do you agree with the following statements? 


\begin{tabular}{|c|c|c|c|c|c|}
\hline & strongly agree & agree & $\begin{array}{l}\text { neither agree nor } \\
\text { disagree }\end{array}$ & disagree & strongly disagree \\
\hline \multicolumn{6}{|l|}{$\begin{array}{l}\text { I have sufficient opportunities for } \\
\text { career progression within my } \\
\text { school/group of schools. }\end{array}$} \\
\hline \multicolumn{6}{|l|}{$\begin{array}{l}\text { I have sufficient opportunities for } \\
\text { career progression in the } \\
\text { education system more widely. }\end{array}$} \\
\hline \multicolumn{6}{|l|}{$\begin{array}{l}\text { I know what I need to do to } \\
\text { achieve the next step in my career. }\end{array}$} \\
\hline \multicolumn{6}{|l|}{$\begin{array}{l}\text { The career paths that are currently } \\
\text { available in the system are } \\
\text { relevant to me. }\end{array}$} \\
\hline $\begin{array}{l}\text { The CPD I attend is relevant to } \\
\text { the next step in my career. }\end{array}$ & & & & & \\
\hline
\end{tabular}

\section{Specialist NPQs}

How likely are you to take up the new specialist Teacher Developer NPQ once it is rolled out?

- Very likely

- Likely

- Unlikely

- Very unlikely

- I don't know

- I haven't heard of it

What content should the new specialist "Teacher Developer" NPQ or other specialist NPQs include?

\section{Retention}

Have you ever considered leaving the teaching profession?

- Yes

- No

- Prefer not to say

Are you currently considering leaving the teaching profession?

- Yes

- No

- Prefer not to say

When are you planning on leaving the teaching profession?

- Within this academic year

- After the end of this academic year

- Within the next $1-5$ years

- Not sure

- Prefer not to say

Would better CPD opportunities encourage you to stay in the profession?

- Yes

- No

What would these CPD opportunities need to fulfil to encourage you to stay in the profession?

What role, if any, does CPD play in encouraging you to stay in the profession?

Personal Information 
In this section we will ask you some information that will help us to contextualise your answers. This information will only be analysed on a group level.

Which of these best describes the setting you currently teach in?

- FE college

- Sixth form college

- Secondary (10-18)

- Secondary (10-16)

- All-through, with sixth form

- All-through, without sixth form

- Middle

- Primary

- Junior

- Nursery

- Infant

- $\quad$ Other (please specify)

How long have you been teaching for?

Have you had any career breaks?

- Yes

- No

- Prefer not to say

How many?

For how long in total?

Reason/s for your career breaks. Tick all that apply.

- Parental Leave

- Other caring responsibilities

- Sabbatical

- Health problems

- Prefer not to say

- Other (please specify)

Is your position full-time?

- Yes

- No

Do you currently have any caring responsibilities? (e.g., young children, elderly relatives, etc.)

- Yes

- No

What is your gender?

- Female

- Male

- Other

- Prefer not to say

What is your ethnicity?

- White British

- White Irish

- White Other

- White and Black Caribbean

- White and Black African

- White and Asian

- Any other mixed background

- Indian 
- Pakistani

- Bangladeshi

- Chinese

- Any other Asian background

- African

- Caribbean

- Any other black background

- Any other ethnic group

53. How old are you?

- $\quad 20-25$

- 26-30

- 31-35

- $36-40$

- $41-45$

- $46-50$

- 51-55

- $56-60$

- $\quad$ over 60

Would you like to participate in phone interviews or online focus groups to provide further information on this topic?

- Yes

- No

Table A1. Survey responses: school phase.

\begin{tabular}{cc}
\hline Respondent's School Phase & Respondents (\%) \\
\hline Sixth form (16-18) & $8 \%$ \\
\hline FE College & $2 \%$ \\
\hline Secondary (11-16) & $27 \%$ \\
\hline Secondary (11-18) & $35 \%$ \\
\hline All-through school (3-18) & $8 \%$ \\
\hline All-through school (3-16) & $2 \%$ \\
\hline Primary (3-11) & $14 \%$ \\
\hline Junior & $2 \%$ \\
\hline Other & $2 \%$ \\
\hline
\end{tabular}


Table A2. Survey responses: teachers' self-efficacy: please indicate below how far you agree with the following statements.

\begin{tabular}{|c|c|c|c|c|c|}
\hline Question & Strongly Agree & Agree & $\begin{array}{l}\text { Neither Agree nor } \\
\text { Disagree }\end{array}$ & Disagree & Strongly Disagree \\
\hline I can control disruptive behaviour & $33.33 \%$ & $59.42 \%$ & $4.35 \%$ & $2.90 \%$ & $0.00 \%$ \\
\hline $\begin{array}{l}\text { I can calm a student who is disruptive } \\
\text { or noisy }\end{array}$ & $26.09 \%$ & $69.57 \%$ & $4.35 \%$ & $0.00 \%$ & $0.00 \%$ \\
\hline I can help students to value learning & $31.88 \%$ & $59.42 \%$ & $7.25 \%$ & $1.45 \%$ & $0.00 \%$ \\
\hline $\begin{array}{l}\text { I can formulate good questions for } \\
\text { my students }\end{array}$ & $46.38 \%$ & $50.72 \%$ & $2.90 \%$ & $0.00 \%$ & $0.00 \%$ \\
\hline $\begin{array}{l}\text { I can get students to follow } \\
\text { classroom rules }\end{array}$ & $44.93 \%$ & $50.72 \%$ & $4.35 \%$ & $0.00 \%$ & $0.00 \%$ \\
\hline $\begin{array}{l}\text { I can get students to believe that they } \\
\text { can do well in school }\end{array}$ & $34.78 \%$ & $53.62 \%$ & $10.14 \%$ & $1.45 \%$ & $0.00 \%$ \\
\hline $\begin{array}{c}\text { I can establish a classroom } \\
\text { management system with each group } \\
\text { of students }\end{array}$ & $39.13 \%$ & $55.07 \%$ & $5.80 \%$ & $0.00 \%$ & $0.00 \%$ \\
\hline $\begin{array}{l}\text { I can use a variety of } \\
\text { assessment strategies }\end{array}$ & $50.00 \%$ & $47.06 \%$ & $2.94 \%$ & $0.00 \%$ & $0.00 \%$ \\
\hline $\begin{array}{l}\text { I can provide alternative explanations } \\
\text { or examples when students } \\
\text { are confused }\end{array}$ & $60.29 \%$ & $36.76 \%$ & $2.94 \%$ & $0.00 \%$ & $0.00 \%$ \\
\hline $\begin{array}{l}\text { I can assist families in helping their } \\
\text { children do well in school }\end{array}$ & $26.47 \%$ & $47.06 \%$ & $23.53 \%$ & $2.94 \%$ & $0.00 \%$ \\
\hline $\begin{array}{l}\text { I can implement alternative teaching } \\
\text { strategies in my classroom }\end{array}$ & $36.23 \%$ & $60.87 \%$ & $2.90 \%$ & $0.00 \%$ & $0.00 \%$ \\
\hline
\end{tabular}

Table A3. Survey responses: barriers to professional development-how strongly do you agree or disagree that the following present barriers to your participation in professional development?

\begin{tabular}{|c|c|c|c|c|c|}
\hline Question & Strongly Disagree & Disagree & $\begin{array}{l}\text { Neither Agree nor } \\
\text { Disagree }\end{array}$ & Agree & Strongly Agree \\
\hline $\begin{array}{l}\text { I do not have the prerequisites (e.g., } \\
\text { qualifications, experience, seniority) }\end{array}$ & $47.54 \%$ & $27.87 \%$ & $16.39 \%$ & $4.92 \%$ & $3.28 \%$ \\
\hline $\begin{array}{l}\text { Professional development is } \\
\text { too expensive }\end{array}$ & $9.84 \%$ & $13.11 \%$ & $18.03 \%$ & $47.54 \%$ & $11.48 \%$ \\
\hline $\begin{array}{l}\text { There is a lack of support from my } \\
\text { school leaders }\end{array}$ & $18.03 \%$ & $22.95 \%$ & $19.67 \%$ & $18.03 \%$ & $21.31 \%$ \\
\hline $\begin{array}{l}\text { Professional development conflicts } \\
\text { with my work schedule }\end{array}$ & $4.92 \%$ & $13.11 \%$ & $19.67 \%$ & $45.90 \%$ & $16.39 \%$ \\
\hline $\begin{array}{l}\text { I do not have time because of family } \\
\text { or other responsibilities }\end{array}$ & $19.67 \%$ & $27.87 \%$ & $21.31 \%$ & $27.87 \%$ & $3.28 \%$ \\
\hline $\begin{array}{l}\text { There is no relevant professional } \\
\text { development offered }\end{array}$ & $31.15 \%$ & $22.95 \%$ & $9.84 \%$ & $22.95 \%$ & $13.11 \%$ \\
\hline $\begin{array}{l}\text { There are no incentives for } \\
\text { participating in } \\
\text { professional development }\end{array}$ & $11.48 \%$ & $18.03 \%$ & $11.48 \%$ & $37.70 \%$ & $21.31 \%$ \\
\hline
\end{tabular}

\section{Appendix B. Regression of Job Satisfaction on Mid-Career Teachers' Experiences of Professional Development}

Table A4 reports the coefficients and standard errors (in parentheses) of regressing the dependent variable of a teacher's satisfaction with their work environment on several independent variables discussed in the main text. All variables were centred and standardised so coefficients can be interpreted similarly to an "effect size," although they show associations rather than causal effects. Four specifications are reported. 
The association between job satisfaction and the barriers to professional development remains the strongest by some margin $(0.36 \mathrm{sd})$ even after conditioning on the other measured aspects of professional development. Including a measure of the number of hours of professional development does not alter the strength of the association. Including measures of school leadership quality reduces it by a third but it remains strong $(0.25 \mathrm{sd})$ and comparable in size to the largest association with leadership $(0.29 \mathrm{sd})$.

Table A4. Regression of job satisfaction on mid-career teachers' experiences of professional development.

\begin{tabular}{|c|c|c|c|c|}
\hline & All Teachers & Mid-Career Teachers 1 & Mid-Career Teachers 2 & Mid-Career Teachers 3 \\
\hline Effectiveness of PD & $\begin{array}{l}0.076^{* *} \\
(0.023)\end{array}$ & $\begin{array}{l}0.103^{* *} \\
(0.033)\end{array}$ & $\begin{array}{l}0.100 * * \\
(0.034)\end{array}$ & $\begin{array}{l}0.107^{* *} \\
(0.034)\end{array}$ \\
\hline Barriers to PD & $\begin{array}{c}-0.362 * * \\
(0.025)\end{array}$ & $\begin{array}{c}-0.358^{* *} \\
(0.037)\end{array}$ & $\begin{array}{c}-0.358^{* *} \\
(0.037)\end{array}$ & $\begin{array}{c}-0.254^{* *} \\
(0.041)\end{array}$ \\
\hline Need for PD & $\begin{array}{c}-0.075^{* *} \\
(0.024)\end{array}$ & $\begin{array}{l}-0.060 \\
(0.045)\end{array}$ & $\begin{array}{l}-0.058 \\
(0.046)\end{array}$ & $\begin{array}{c}-0.085 * \\
(0.045)\end{array}$ \\
\hline Hours of PD & No & No & Yes & Yes \\
\hline Quality of leadership & No & No & No & Yes \\
\hline $\mathrm{n}$ & & & & \\
\hline
\end{tabular}

\section{References}

1. See, B.H.; Morris, R.; Gorard, S.; Kokotsaki, D.; Abdi, S. Teacher recruitment and retention: A critical review of international evidence of most promising interventions. Educ. Sci. 2020, 10, 262. [CrossRef]

2. See, B.H.; Gorard, S. Why don't we have enough teachers? A reconsideration of the available evidence. Res. Pap. Educ. 2020, 35, 416-442. [CrossRef]

3. Sutcher, L.; Darling-Hammond, L.; Carver-Thomas, D. A Coming Crisis in Teaching? Teacher Supply, Demand, and Shortages in the U.S.; Learning Policy Institute: Palo Alto, CA, USA, 2016.

4. Dee, T.S.; Goldhaber, D. Understanding and Addressing Teacher Shortages in the United States; Hamilton Project Report 2017-05; The Brookings Institution: Washington, DC, USA, 2017.

5. Fisher, M.H.; Royster, D. Mathematics teachers' support and retention: Using Maslow's hierarchy to understand teachers' needs. Int. J. Math. Educ. Sci. Technol. 2016, 47, 993-1008. [CrossRef]

6. Weldon, P. Early career teacher attrition in Australia: Evidence, definition, classification and measurement. Aust. J. Educ. 2018, 62, 61-78. [CrossRef]

7. Mason, S.; Matas, C.P. Teacher attrition and retention research in Australia: Towards a new theoretical framework. Aust. J. Teach. Educ. Online 2015, 40, 45-66. [CrossRef]

8. Birch, P.; Balcon, M.-P.; Bourgeois, A.; Davydovskaia, O.; Tremosa, S.P. Teaching Careers in Europe: Access, Progression and Support; Eurydice Report; Publications Office of the European Union: Luxembourg, 2018.

9. Ingersoll, R.; May, H. Recruitment, Retention and the Minority Teacher Shortage. 2011. Available online: https:/ /www.cpre.org/ sites/default/files/researchreport/1221_minorityteachershortagereportrr69septfinal.pdf (accessed on 30 April 2021).

10. Grudnoff, L. All's well? New Zealand beginning teachers' experience of induction provision in their first six months in school. Prof. Dev. Educ. 2012, 38, 471-485. [CrossRef]

11. Den Brok, P.; Wubbels, T.; Van Tartwijk, J. Exploring beginning teachers' attrition in The Netherlands. Teach. Teach. 2017, 23, 881-895. [CrossRef]

12. Gallant, A.; Riley, P. Early career teacher attrition in Australia: Inconvenient truths about new public management. Teach. Teach. 2017, 23, 896-913. [CrossRef]

13. Towers, E.; Maguire, M. Leaving or staying in teaching: A 'Vignette'of an experienced urban teacher 'Leaver'of a London primary school. Teach. Teach. 2017, 23, 946-960. [CrossRef]

14. Perryman, J.; Calvert, G. What motivates people to teach, and why do they leave? Accountability, performativity and teacher retention. Br. J. Educ. Stud. 2020, 68, 3-23. [CrossRef]

15. Tricarico, K.M.; Jacobs, J.; Yendol-Hoppey, D. Reflection on their first five years of teaching: Understanding staying and impact power. Teach. Teach. 2015, 21, 237-259. [CrossRef]

16. Eros, J. The career cycle and the second stage of teaching: Implications for policy and professional development. Arts Educ. Policy Rev. 2011, 112, 65-70. [CrossRef]

17. Sibieta, L. Teacher Shortages in England: Analysis and Pay Options; Education Policy Institute: London, UK, 2020. 
18. Department for Education. Initial Teacher Training: Trainee Number Census 2020 to 2021. Department for Education: London, UK, 2020. Available online: https://www.gov.uk/government/statistics/initial-teacher-training-trainee-number-census-2020 -to-2021 (accessed on 15 June 2021).

19. Worth, J.; McLean, D.; National Foundation for Educational Research (NFER) (UK). The Impact of Covid-19 on Initial Teacher Training; National Foundation for Educational Research (NFER): Slough, UK, 2020.

20. Department for Education Teacher Recruitment and Retention Strategy. 2019. Available online: https://www.gov.uk/ government/publications/teacher-recruitment-and-retention-strategy (accessed on 30 April 2021).

21. Allen, R.; Sims, S. Do pupils from low-income families get low-quality teachers? Indirect evidence from English schools. Oxf. Rev. Educ. 2018, 44, 441-458. [CrossRef]

22. Donaldson, M.; Johnson, S.M. The price of misassignment: The role of teaching assignments in teach for America teachers' exit from low-income schools and the teaching profession. Educ. Eval. Policy Anal. 2010, 32, 299-323. [CrossRef]

23. Organisation for Economic Co-operation and Development (OECD). TALIS 2018 Results (Volume II): Teachers and School Leaders as Valued Professionals; Organisation for Economic Co-operation and Development (OECD): Paris, France, 2020.

24. Donaldson, G. Teaching Scotland's Future Report of a Review of Teacher Education in Scotland; The Scottish Government: Edinburgh, UK, 2010.

25. Ronfeldt, M.; Loeb, S.; Wyckoff, J. How teacher turnover harms student achievement. Am. Educ. Res. J. 2012, 50, 4-36. [CrossRef]

26. Atteberry, A.; Loeb, S.; Wyckoff, J. Teacher churning: Reassignment rates and implications for student achievement. Educ. Eval. Policy Anal. 2016, 20, 1-28. [CrossRef]

27. Boyd, D.; Grossman, P.; Ing, M.; Lankford, H.; Loeb, S.; Wyckoff, J. The influence of school administrators on teacher retention decisions. Am. Educ. Res. J. 2011, 48, 303-333. [CrossRef]

28. Coldwell, M. Career orientations and career cultures: Individual and organisational approaches to beginning teachers' careers. Teach. Teach. 2016, 22, 610-624. [CrossRef]

29. Ovenden-Hope, T.; Blandford, S.; Cain, T.; Maxwell, B. Retain early career teacher retention programme: Evaluating the role of research informed continuing professional development for a high quality, sustainable 21st century teaching profession. J. Educ. Teach. 2018, 44, 590-607. [CrossRef]

30. Gordon, A.L. Educate-Mentor-Nurture: Improving the transition from initial teacher education to qualified teacher status and beyond. J. Educ. Teach. 2020, 46, 664-675. [CrossRef]

31. Johnson, B.; Down, B.; Le Cornu, R.; Peters, J.; Sullivan, A.; Pearce, J.; Hunter, J. Promoting early career teacher resilience: A framework for understanding and acting. Teach. Teach. 2014, 20, 530-546. [CrossRef]

32. Department for Education Early Career Framework. 2019. Available online: https://www.gov.uk/government/publications/ early-career-framework (accessed on 30 April 2021).

33. Department for Education National Professional Qualifications (NPQs) Reforms. 2021. Available online: https://www.gov. uk/government/publications/national-professional-qualifications-npqs-reforms/national-professional-qualifications-npqsreforms (accessed on 30 April 2021).

34. Taylor, M.; Yates, A.; Meyer, L.H.; Kinsella, P. Teacher professional leadership in support of teacher professional development. Teach. Teach. Educ. 2011, 27, 85-94. [CrossRef]

35. Kirkpatrick, C.L. To invest, coast or idle: Second stage teachers enact their job engagement. In Proceedings of the American Education Research Association Annual Conference, Chicago, IL, USA, 9-13 April 2007.

36. Hartshorne, R.; Baumgartner, E.; Kaplan-Rakowski, R.; Mouza, C.; Ferdig, R.E. Special issue editorial: Preservice and inservice professional development during the COVID-19 pandemic. J. Technol. Teach. Educ. 2020, 28, 137-147.

37. Organisation for Economic Co-operation and Development (OECD). Creating Effective Teaching and Learning Environments: First Results from TALIS; TALIS, OECD Publishing: Paris, France, 2009. [CrossRef]

38. Levac, D.; Colquhoun, H.; O’Brien, K.K. Scoping studies: Advancing the methodology. Implement. Sci. 2010, 5, 69. [CrossRef] [PubMed]

39. Mays, N.; Roberts, E.; Popay, J. Synthesising research evidence. In Methods for Studying the Delivery and Organisation of Health Services; Fulop, N., Allen, P., Clarke, A., Black, N., Eds.; Routledge: London, UK, 2001.

40. Sharma, U.; Rangarajan, R. Teaching students with autism spectrum disorders in South Asia: A scoping study and recommendations for future. Int. J. Dev. Disabil. 2019, 65, 347-358. [CrossRef]

41. Arksey, H.; O’Malley, L. Scoping studies: Towards a methodological framework. Int. J. Soc. Res. Methodol. 2005, 8, 19-32. [CrossRef]

42. Munn, Z.; Peters, M.D.; Stern, C.; Tufanaru, C.; McArthur, A.; Aromataris, E. Systematic review or scoping review? Guidance for authors when choosing between a systematic or scoping review approach. BMC Med. Res. Methodol. 2018, 18, 1-7. [CrossRef]

43. Spilsbury, K.; Pender, S.; Bloor, K.; Borthwick, R.; Atkin, K.; McCaughan, D.; Watt, I.; Adderley, U.; Wakefield, A.; McKenna, H. Support matters: A mixed methods scoping study on the use of assistant staff in the delivery of community nursing services in England. Health Serv. Deliv. Res. 2013, 1, 1-146. [CrossRef] [PubMed]

44. Schofield, B.; Voss, S.; Proctor, A.; Benger, J.; Coates, D.; Kirby, K.; Purdy, S.; Booker, M. Exploring how paramedics are deployed in general practice and the perceived benefits and drawbacks: A mixed-methods scoping study. BJGP Open 2020, 4. [CrossRef] [PubMed] 
45. Anderson, S.; Allen, P.; Peckham, S.; Goodwin, N. Asking the right questions: Scoping studies in the commissioning of research on the organisation and delivery of health services. Health Res. Policy Syst. 2008, 6, 7. [CrossRef]

46. Greenhalgh, T.; Robert, G.; Macfarlane, F.; Bate, P.; Kyriakidou, O.; Peacock, R. Storylines of research in diffusion of innovation: A meta-narrative approach to systematic review. Soc. Sci. Med. 2005, 61, 417-430. [CrossRef]

47. Allen, R.; Benhenda, A.; Jerrim, J.; Sims, S. New evidence on teachers' working hours in England. An empirical analysis of four datasets. Res. Pap. Educ. 2020, 1-25. [CrossRef]

48. Jerrim, J.; Sims, S. The Teaching and Learning International Survey (TALIS) 2018; UCL Institute of Education: London, UK, 2019.

49. Burns, D.; Darling-Hammond, L. Teaching Around the World: What Can TALIS Tell Us; Stanford Center for Opportunity Policy in Education: Stanford, CA, USA, 2014; Available online: https://edpolicy.stanfor.edu/sites/default/files/publications/teachingaround-world-what-can-talis-tell-us_3.pdf (accessed on 15 June 2021).

50. Freeman, C.; O'Malley, K.; Eveleigh, F. Australian Teachers and the Learning Environment: An Analysis of Teacher Response to TALIS 2013; Australian Council for Educational Research: Melbourne, Australia, 2014.

51. Jenkins, A.; Ueno, A. Classroom disciplinary climate in secondary schools in England: What is the real picture? Br. Educ. Res. J. 2017, 43, 124-150. [CrossRef]

52. Organisation for Economic Co-operation and Development (OECD). TALIS 2018 Technical Report; Organisation for Economic Co-operation and Development (OECD): Paris, France, 2019; Available online: https://www.oecd.org/education/talis/TALIS_ 2018_Technical_Report.pdf (accessed on 15 June 2021).

53. Sims, S.; Jerrim, J. TALIS 2018: Teacher Working Conditions, Turnover and Attrition; Department for Education: London, UK, 2020; p. 59.

54. Department for Education. School Workforce in England: November 2019; Department for Education: London, UK, 2020.

55. Huberman, M. The professional life cycle of teachers. Teach. Coll. Rec. 1989, 91, 31-57.

56. Dreyfus, S.E. The five-stage model of adult skill acquisition. Bull. Sci. Technol. Soc. 2004, 24, 177-181. [CrossRef]

57. Day, C.; Stobart, G.; Sammons, P.; Kington, A. Variations in the work and lives of teachers: Relative and relational effectiveness. Teach. Teach. 2006, 12, 169-192. [CrossRef]

58. Day, C. New lives of teachers. Teach. Educ. Q. 2012, 39, 7-26.

59. Day, C.; Gu, Q. Variations in the conditions for teachers' professional learning and development: Sustaining commitment and effectiveness over a career. Oxf. Rev. Educ. 2007, 33, 423-443. [CrossRef]

60. Day, C.; Gu, Q. The New Lives of Teachers; Routledge: London, UK, 2010.

61. Borman, G.D.; Dowling, N.M. Teacher attrition and retention: A meta-analytic and narrative review of the research. Rev. Educ. Res. 2008, 78, 367-409. [CrossRef]

62. Bressman, S.; Winter, J.S.; Efron, S.E. Next generation mentoring: Supporting teachers beyond induction. Teach. Teach. Educ. 2018, 73, 162-170. [CrossRef]

63. Fullan, M.G. Why teachers must become change agents. Educ. Leadersh. 1993, 50, 12.

64. Fessler, R.; Christensen, J. The Teacher Career Cycle: Understanding and Guiding the Professional Development of Teachers; Allyn and Bacon: Boston, MA, USA, 1992.

65. Dall'Alba, G.; Sandberg, J. Unveiling professional development: A critical review of stage models. Rev. Educ. Res. 2006, 76, 383-412. [CrossRef]

66. Maandag, D.; Helms-Lorenz, M.; Lugthart, E.; Verkade, A.T.; Van Veen, K. Features of Effective Professional Development Interventions in Different Stages of Teachers' Careers; University of Groningen: Groningen, The Netherlands, 2017.

67. Berliner, D.C. Expert teachers: Their characteristics, development and accomplishments. In De La Teoria ... a L'aula: Formacio del Professorat Ensenyament de las Ciències Socials; Batllori i Obiols, R., Gomez Martinez, A.E., Oller i Freixa, M., Pages i Blanch, J., Eds.; Universitat Autònoma de Barcelona: Barcelona, Spain, 2004; pp. 13-28.

68. Day, C.; Sammons, P.; Stobart, G. Teachers Matter: Connecting Work, Lives and Effectiveness; McGraw-Hill Education: London, UK, 2007.

69. Steffy, B.E.; Wolfe, M.P. A life-cycle model for career teachers. Kappa Delta Pi Rec. 2001, 38, 16-19. [CrossRef]

70. Avidov-Ungar, O.; Herscu, O. Formal professional development as perceived by teachers in different professional life periods. Prof. Dev. Educ. 2020, 46, 833-844. [CrossRef]

71. Mertler, C.A. Classroom-Based action research: Revisiting the process as customizable and meaningful professional development for educators. J. Pedagog. Dev. 2013, 3, 39-43.

72. Klassen, R.M.; Chiu, M.M. Effects on teachers' self-efficacy and job satisfaction: Teacher gender. Years Exp. Job Stress J. Educ. Psychol. 2010, 102, 741-756.

73. Kyndt, E.; Gijbels, D.; Grosemans, I.; Donche, V. Teachers' everyday professional development: Mapping informal learning activities, antecedents, and learning outcomes. Rev. Educ. Res. 2016, 86, 1111-1115. [CrossRef]

74. Schwille, S.A. Never Give Up: An Experienced Teacher Overcomes Obstacles to Change; IAP: Charlotte, NC, USA, 2016.

75. Maurer, T.J.; Tarulli, B.A. Investigation of Perceived environment, perceived outcome, and person variables in relationship to voluntary development activity by employees. J. Appl. Psychol. 1994, 79, 3. [CrossRef]

76. Richter, D.; Kunter, M.; Klusmann, U.; Lüdtke, O.; Baumert, J. Professional development across the teaching career: Teachers' uptake of formal and informal learning opportunities. Teach. Teach. Educ. 2011, 27, 116-126. [CrossRef]

77. Brown, S. Part-Time Women Teachers and Their Career Progression: A Life History Approach. Ph.D. Thesis, Sheffield Hallam University, Sheffield, UK, 2019. 
78. Louws, M.L.; Meirink, J.A.; van Veen, K.; van Driel, J.H. Understanding teachers' professional learning goals from their current professional concerns. Teach. Teach. 2018, 24, 63-80. [CrossRef]

79. Louws, M.L.; Meirink, J.A.; van Veen, K.; van Driel, J.H. Teachers' self-directed learning and teaching experience: What, how, and why teachers want to learn. Teach. Teach. Educ. 2017, 66, 171-183. [CrossRef]

80. Donaldson, M.L.; Johnson, S.M.; Kirkpatrick, C.L.; Marinell, W.; Steele, J.L.; Szczesiul, S.A. Angling for access, bartering for change: How second-stage teachers experience differentiated roles in schools. Teach. Coll. Rec. 2008, 110, $1088-1114$.

81. Mertler, C.A. Should I stay or should I go? Understanding teacher motivation, job satisfaction, and perceptions of retention among Arizona teachers. Int. Res. High. Educ. 2016, 1, 34-45. [CrossRef]

82. Department for Education; Michelle Donelan, M.P. Opportunity Areas Programme to Support Young People Hit Hardest by Pandemic. Available online: https:/ / www.gov.uk/government/news/opportunity-areas-programme-to-support-youngpeople-hit-hardest-by-pandemic (accessed on 25 April 2021).

83. Chartered College of Teaching Chartered Status. Available online: https://chartered.college/chartered-teacher/ (accessed on 25 April 2021).

84. Worth, J.; Bamford, S.; Durbin, B. Should I Stay or Should I Go? NFER Analysis of Teachers Joining and Leaving the Profession; NFER: Slough, UK, 2015.

85. Sims, S. TALIS 2013: Working Conditions, Teacher Job Satisfaction and Retention; Department for Education: London, UK, 2017.

86. Coldwell, M. Exploring the influence of professional development on teacher careers: Developing a path model approach. Teach. Teach. Educ. 2017, 61, 189-198. [CrossRef]

87. Speck, D. Revealed: The 8 Lead Schools for Teacher Flexi Working. Available online: https://www.tes.com/news/revealed-8lead-schools-teacher-flexible-working-part-time (accessed on 26 April 2021). 